\title{
Socialist People's Libyan Arab Jamahiriya: 2008 Article IV Consultation-Staff Report; Public Information Notice on the Executive Board Discussion; and Statement by the Executive Director for the Socialist People's Libyan Arab Jamahiriya.
}

Under Article IV of the IMF's Articles of Agreement, the IMF holds bilateral discussions with members, usually every year. In the context of the 2008 Article IV consultation with the Socialist People's Libyan Arab Jamahiriya, the following documents have been released and are included in this package:

- $\quad$ The staff report for the 2008 Article IV consultation, prepared by a staff team of the IMF, following discussions that ended on May 14, 2008 with the officials of the Socialist People's Libyan Arab Jamahiriya on economic developments and policies. Based on information available at the time of these discussions, the staff report was completed on July 3, 2008. The views expressed in the staff report are those of the staff team and do not necessarily reflect the views of the Executive Board of the IMF.

- $\quad$ A Public Information Notice (PIN) summarizing the views of the Executive Board as expressed during its July 18, 2008 discussion of the staff report that concluded the Article IV consultation.

- $\quad$ A statement by the Executive Director for the Socialist People's Libyan Arab Jamahiriya.

The document listed below will be separately released.

\section{Statistical Appendix}

The policy of publication of staff reports and other documents allows for the deletion of market-sensitive information.

Copies of this report are available to the public from

International Monetary Fund • Publication Services $70019^{\text {th }}$ Street, N.W. • Washington, D.C. 20431

Telephone: (202) 623-7430 • Telefax: (202) 623-7201

E-mail: publications@imf.org •Internet: http://www.imf.org

Price: $\$ 18.00$ a copy

\section{International Monetary Fund} Washington, D.C. 



\title{
INTERNATIONAL MONETARY FUND
}

\section{SOCIALIST PEOPLE'S LIBYAN ARAB JAMAHIRIYA}

Staff Report for the 2008 Article IV Consultation

\author{
Prepared by the Staff Representatives for the 2008 Consultation with \\ the Socialist People's Libyan Arab Jamahiriya \\ Approved by Amor Tahari and Adnan Mazarei
}

July 3, 2008

- Discussions for the 2008 Article IV consultation were held in Tripoli during April 30-May 14, 2008. The staff team comprised Messrs. Sakr (Head), Al-Ghelaiqah, Dridi, El Said, and Almounsor (all MCD), and Mr. Zoromé (MCM).

- The mission met with Messrs. Zlitni, Secretary of Planning; Al-Huweij, Secretary of Finance; Al-Eisawi, Secretary of Economy; Bengdara, Governor of the Central Bank of Libya, and other officials and private sector representatives.

- The previous consultation report and summing-up are available at http://www.imf.org/external/np/sec/pn/ 2007/ pn0746.htm.

- Libya has accepted the obligations of Article VIII and maintains an exchange system free of restrictions on the making of payments and transfers for current international transactions.

- $\quad$ The Libyan dinar is pegged to the SDR at LD 1.93 per SDR. 


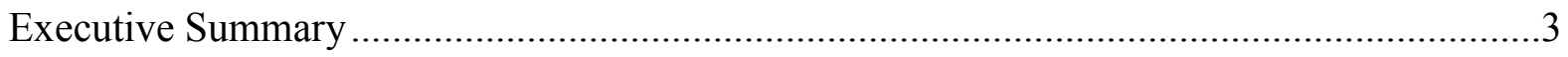

I. Background and Recent Developments..................................................................

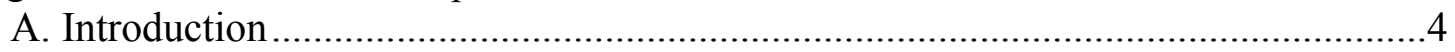

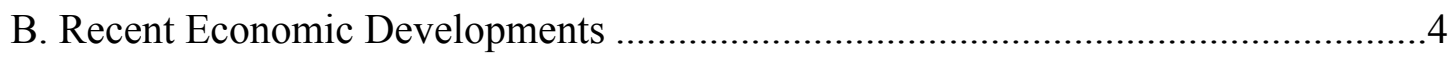

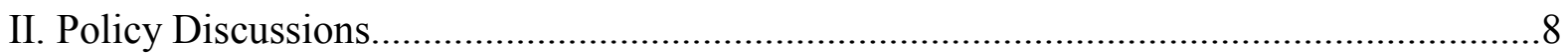

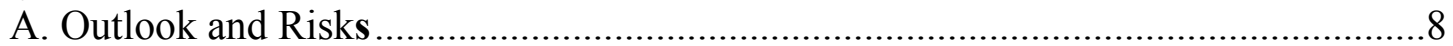

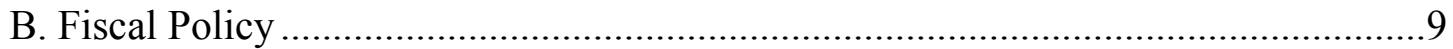

C. Monetary Policy and Financial Sector Reform ................................................ 10

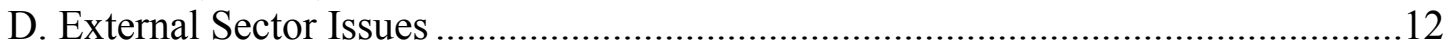

E. Structural Reforms and Other Issues .............................................................. 12

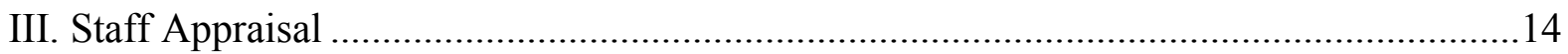

\section{Boxes}

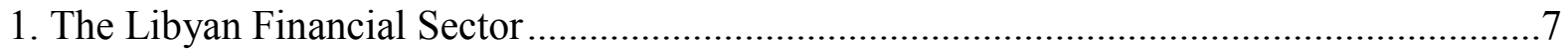

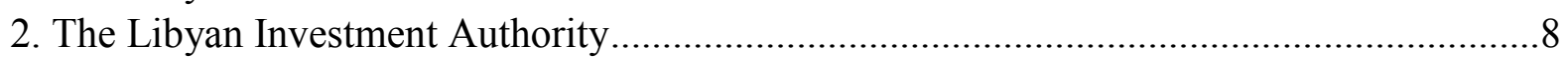

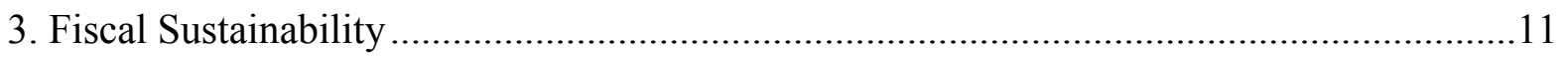

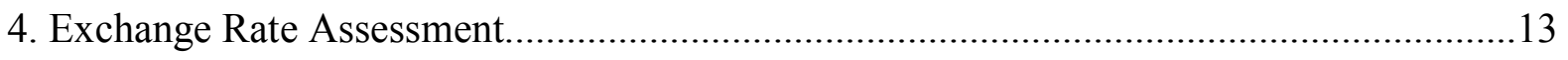

Figures

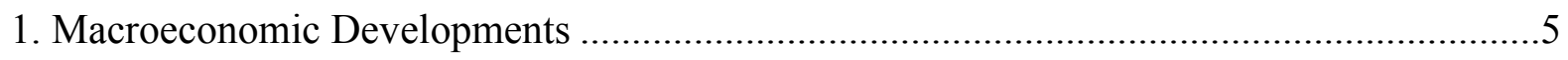

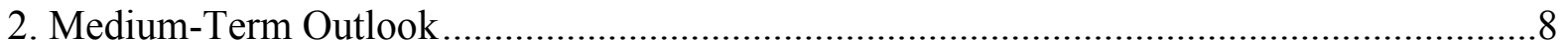

\section{Tables}

1. Basic Economic and Financial Indicators, 2004-08 ...................................................... 17

2. Consolidated Fiscal Operations, 2004-08 .................................................................... 18

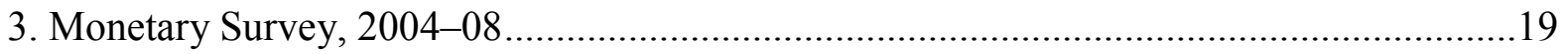

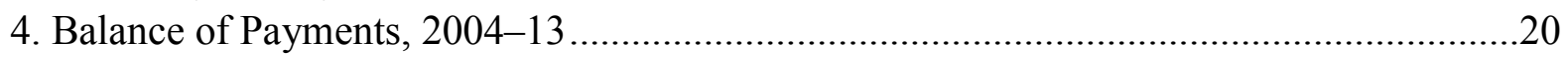

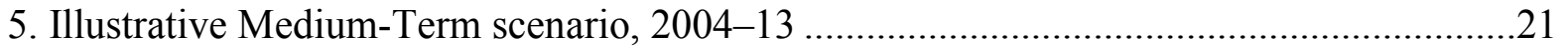

6. Financial Soundness Indicators, 2002-07.............................................................22 


\section{EXECUTIVE SUMMARY}

The 2008 Article IV consultation discussions with Libya were held against the backdrop of high oil revenue and large expenditure plans. The discussions focused on containing public expenditure in order to reduce inflationary pressures, strengthening the monetary policy framework, and advancing financial sector reforms.

\section{Economic developments and outlook}

Libya's macroeconomic performance has been strong. GDP growth is broad-based and has strengthened further. Inflation, however, increased substantially in 2007 and has accelerated further in 2008. Both the fiscal and external current account positions are in large surpluses, and net foreign assets are accumulating rapidly. The medium-term outlook is favorable, underpinned by the expectation of high oil prices and increased infrastructure spending. A Wealth Distribution Program (WDP) was launched in March 2008 to distribute part of the oil revenue to the population and downsize public administration. The Libyan Investment Authority (LIA) was established in March 2007 and its operational framework has been enhanced broadly in line with staff recommendations.

\section{Authorities' views}

- $\quad$ Large public outlays are necessary to upgrade the infrastructure and share the oil wealth with the population.

- The acceleration in inflation has been driven mostly by higher import prices. To help reduce its domestic component, capital expenditure is being rationalized.

- Implementation of financial sector and other structural reforms will continue to be advanced to promote private sector development and employment.

\section{Staff recommendations}

- $\quad$ Public expenditure should be further rationalized if inflation does not decline. Prioritization would also preserve the quality of expenditure, and appropriate sequencing would minimize bottlenecks and shortages.

- $\quad$ The scope of the WDP needs to be reduced in order to limit expenditure growth and maintain intergenerational equity. The restructuring of public administration should be carefully considered in close consultation with the World Bank.

- The dinar's peg to the SDR has served Libya well. An eventual move to greater exchange rate flexibility would be beneficial, but would need to be gradual and preceded by a switch to marketbased monetary management.

- The commendable efforts to reform the financial sector and enhance the monetary policy framework should continue.

- Staff encourages the authorities to limit any domestic investments by the LIA and to continue to enhance its operational framework in line with the evolving best practices for sovereign wealth funds. 


\section{BACKGROUND AND RECENT DEVELOPMENTS}

\section{A. Introduction}

\section{The discussions were held against the backdrop of high oil revenue, robust} growth, rapid increase in public expenditure, and rising inflation. The normalization of diplomatic relations with the U.S. and the EU in the second half of 2007 has contributed to increased foreign investors' interest, particularly in the hydrocarbon, banking, and infrastructure sectors. A Wealth Distribution Program (WDP) was launched in March 2008 to distribute part of the oil wealth to the population and reduce the size of the government. ${ }^{1}$ Disbursements will be in the form of both cash and shares in projects. The initially announced amount was LD 25-30 billion (\$20-25 billion), but only LD 4.6 billion ( $\$ 3.8$ billion) were subsequently approved for this year. The authorities are still considering the size, form, and modalities of the annual distributions in the years ahead.

2. Past Fund policy advice has centered on the need to restore fiscal prudence, strengthen oil revenue management, develop a well-designed strategy to restructure public commercial banks, and advance structural reforms. The authorities have made good progress in some of these areas, particularly bank restructuring and privatization, the establishment of a modern sovereign wealth fund, and the initiation of an ambitious civil service reform.

\section{B. Recent Economic Developments}

3. Macroeconomic performance strengthened further in 2007, notwithstanding an acceleration in inflation. Real GDP grew by 6.8 percent, supported by an expansion in the hydrocarbon sector (3.9 percent) and a rapid increase in non-hydrocarbon activities (10.3 percent). ${ }^{2}$ Growth was particularly pronounced in construction, transportation, and trade. At the same time, average inflation increased substantially to 6.2 percent, largely driven by higher food prices and a marked increase in public expenditure. ${ }^{3}$ Inflation has accelerated further thus far in 2008, averaging about 12 percent in the first quarter (year-onyear).

4. Despite higher oil revenues, Libya's fiscal surplus in 2007 narrowed to 26 percent of GDP, compared to 35 percent in 2006. This reflected a rapid increase in virtually all

\footnotetext{
${ }^{1}$ This downsizing will be in addition to the large civil service reduction program, which started before the WDP was launched.

${ }^{2}$ Libya is the third largest African oil producer and has the largest proven reserves in the continent (43.7 billion barrels at end-2007). Libya comes fourth in Africa in terms of natural gas production and reserves (equivalent to about 0.25 million barrels per day and 9 billion barrels of oil, respectively).

${ }^{3}$ The largest contributor to inflation was the rise in food prices (12 percent), followed by dwelling ( 7 percent). The increase in the prices of other items was much smaller.
} 
expenditure items (45 percent). The wage bill increased by around 50 percent. The raise in public wages was accompanied by an initiation of a large civil service reform, with about one third of public employees being transferred to a central labor office for retraining or retrenchment.

\section{Figure 1. Libya: Macroeconomic Developments}
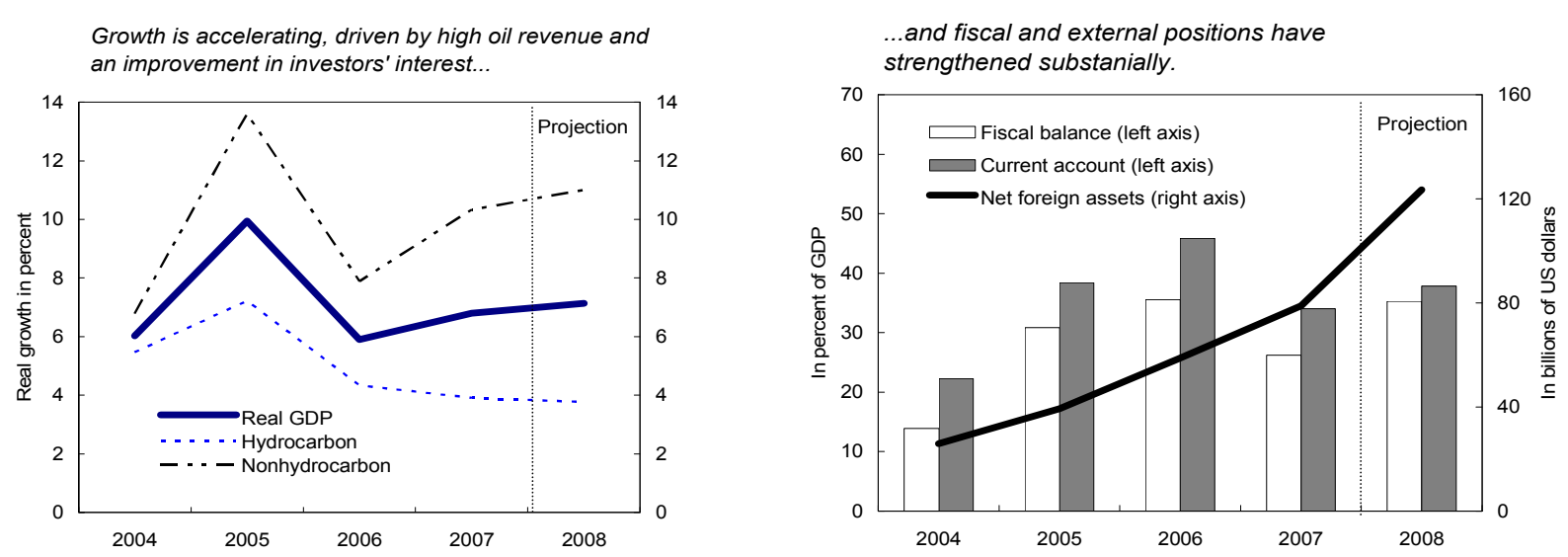

Public expenditure is increasing rapidly..
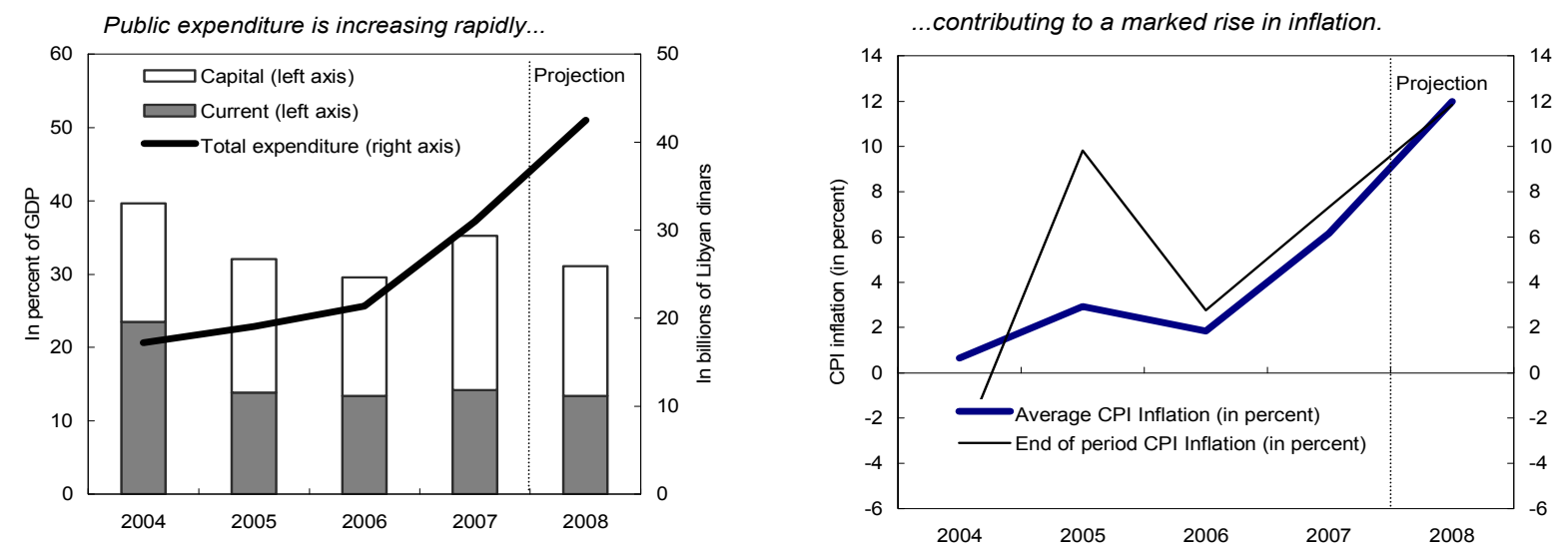

The depreciation in the REER since exchange rate unfication has decelerated..

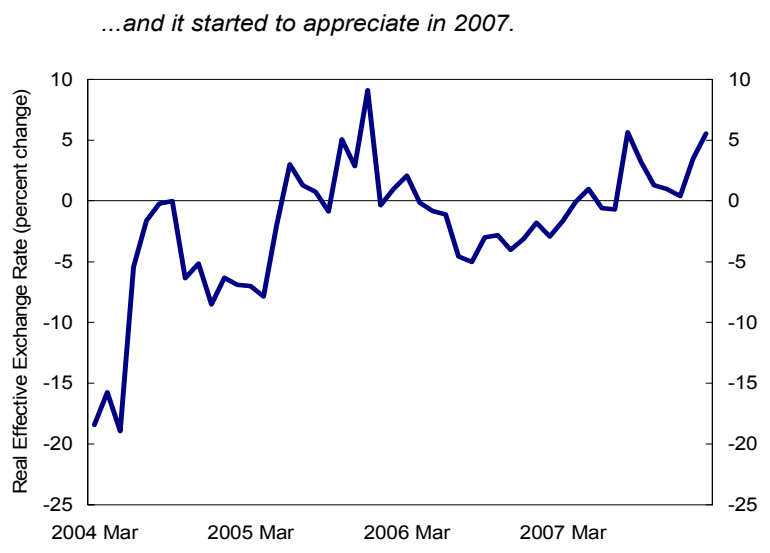

Source: Libyan Authorities; and Fund staff estimates. 
5. The external current account surplus also narrowed in 2007. It declined to 34 percent of GDP, compared to 46 percent in 2006, due to a marked increase in imports (33 percent). Continued high oil exports resulted in a further build up of the net foreign assets of the Central Bank of Libya (CBL) to almost $\$ 80$ billion. The real effective exchange rate of the dinar appreciated by 1 percent in 2007, and about 5 percent in the first quarter of 2008 due to the combined effects of the rising inflation and the strengthening of the euro. ${ }^{4}$

6. Broad money growth more than doubled to 41 percent in 2007 , reflecting the substantial increase in net foreign assets and the rapid increase in public expenditure, including on-lending by specialized credit institutions (SCIs). Credit to the nongovernment sector extended by these institutions grew by about 36 percent, while that extended by commercial banks grew by about 15 percent. Interest rates remained low and became largely negative in real terms with the rise in inflation. ${ }^{5}$

7. Notable progress has been made in banking sector reforms (Box 1). Two of the three remaining public commercial banks were merged in April 2008. Most regional banks have also been merged into one bank, and agreement has been reached with financial institutions from UAE and Qatar to establish two new banks.

8. Commercial banks are well capitalized, but the quality of their assets needs to be further improved. Their overall capital adequacy ratio stood at about 15 percent at end2007. However, nonperforming loans (NPLs) constituted 25 percent of total loans. While still high, this ratio compares favorably to its peak of almost 36 percent in 2004. Provisioning for these loans has increased to about 67 percent.

9. The Libyan Investment Authority (LIA) was established in March 2007. The authorities plan to invest the LIA's initial \$40-50 billion on a commercial basis and ensure that the LIA will be run by a qualified and independent management. Recent enhancements of its operational framework are largely in line with staff's recommendations (Box 2).

\footnotetext{
${ }^{4}$ The euro area is Libya's largest trading partner.

5 The interest rates on CBL's CDs and on 1-year deposits stood at 2.25 and 4.5 percent, respectively, at endApril 2008.
} 


\section{Box 1. The Libyan Financial Sector}

- The Libyan financial system is small. It comprises eleven commercial banks, four SCIs, 48 regional banks (most of which have already been merged), one exchange bureau, and five insurance companies. The five largest commercial banks were all state-owned until 2006. Since then, two have been privatized and two merged. The SCIs are also state-owned and financed by the government.

- Financial intermediation continues to be low in Libya compared to other Maghreb countries. Commercial banks' credit has been on a downward trend (reaching 13 percent of GDP in 2007) as it was being crowded-out by credit from SCIs.
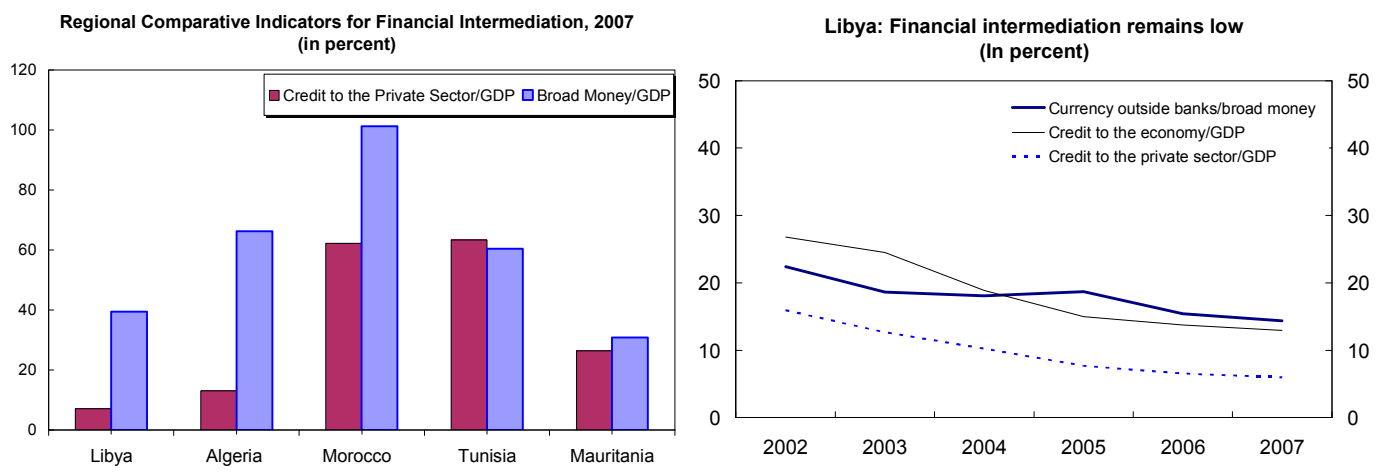

- Bank privatization started in 2007. BNP Paribas acquired 19 percent of Sahara Bank in August 2007, with immediate management control and option to purchase additional shares of up to 51 percent within 3-5 years. Wahda Bank was acquired by Arab Bank in February 2008 under similar terms.

- Tangible progress has been made in banking supervision, but important shortcomings remain. In particular, there is a need to strengthen licensing procedures, the reporting of banks' financial statements, and on-site inspection. The CBL is implementing a substantial IMF TA program, including with METAC, to improve capacity in off-site supervision, loan classifications, and capital adequacy calculation. Furthermore, the authorities reached a technical cooperation agreement with the Fund to field peripatetic and resident experts in banking supervision and central bank restructuring.

- The capital and insurance market are in their infancy. The stock exchange was established in 2006. By end-2007, seven companies (mostly banks) were listed with a capitalization of LD 1.2 billion (1.4 percent of GDP). The insurance sector is small and largely underdeveloped, with total market premium income at LD 190 million in 2006. 
Box 2. The Libyan Investment Authority

- The LIA started operations in June 2007 to manage the financial assets allocated to it by the State, including the Oil Reserve Fund. The intention is to build a high quality and well-diversified investment portfolio in order to create a high and sustainable source of revenue, with a view to reducing dependency on oil. The LIA consolidated pre-existing funds such as the Libya Foreign Investment Company and the Libyan African Investment Portfolio.

- $\quad$ The LIA invests its assets on a commercial basis mostly abroad through reputable international managers. It may, however, make direct investments domestically or internationally with strategic partners. Its organizational structure is being developed with assistance from international consultants. Its Board of Trustees is headed by the prime minister and its Board of Directors is advised by a committee of international financial experts. An international consulting firm is helping the LIA develop a process for selecting and evaluating reputable investment managers for the different asset classes. The LIA intends to meet high transparency standards.

- Staff reviewed the LIA draft law in November 2007 and recommended revisions to remove or limit the provisions that would allow the LIA to invest domestically, on-lend, and play a developmental role. Staff also recommended that the LIA's relationship with the state budget be clarified further, including by explicitly allowing larger withdrawals from the LIA under exceptional circumstances, and that more specific transparency requirements be spelled out. A decree was issued in March 2008, broadly encompassing staff's recommendations.

\section{Policy Discussions}

10. Against the above background, the policy discussions focused on containing expenditure growth, enhancing the monetary policy framework, and further advancing financial sector reforms.

\section{A. Outlook and Risks}

\section{Libya's economic growth and financial position are expected to strengthen}

\section{further in 2008 and over the} medium term as a result of high oil receipts, the upgrading of the infrastructure, and increased interest of foreign investors. Oil production is projected to increase substantially to about 3 million barrels per day by 2013 on account of large investments and the utilization of advanced technologies by foreign partners. Many projects in the nonhydrocarbon sectors are intended

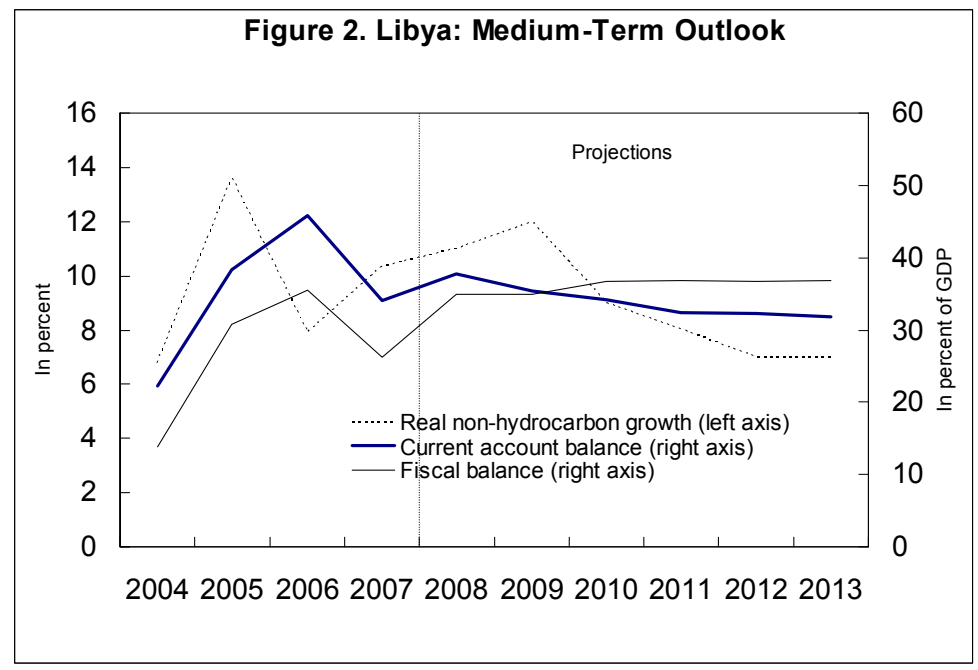


to be completed by the $40^{\text {th }}$ anniversary of the revolution in 2009 . The growth of both public expenditure and imports is, therefore, expected to decelerate to a more moderate pace starting in 2010. Taking into account the authorities' intention to continue to prioritize public expenditure, it is projected to stabilize as a percent of GDP. The fiscal surplus is thus expected to slightly increase to 37 percent of GDP over the medium term, while the external current account surplus is projected to moderate to 32 percent. A stabilization of international food prices and a careful sequencing of investment projects to minimize bottlenecks and shortages would help put inflation on a downward trend. The authorities broadly agreed with the outlook described above.

12. This favorable outlook is subject to downside risks, especially if oil prices turn out lower than projected or the resolve to limit public expenditure growth (including in the context of the WDP) wavers. If these risks materialize, the fiscal and external balances could be considerably weaker than the above projections, with adverse consequences on intergenerational equity, and inflation could further increase beyond its present low double-digit level. A further acceleration in public expenditure would also likely lead to deterioration in its quality, with negative implications for the GDP growth outlook.

\section{B. Fiscal Policy}

\section{The $\mathbf{2 0 0 8}$ budget reflects a continuation of the expansionary fiscal stance as it} entails a large increase in public expenditure. Current expenditure is envisaged to increase by about 50 percent, compared to 2007, largely on account of transfers related to the WDP. The total of the wage bill and monthly transfers related to severance payments are projected to increase by around 15 percent. Capital expenditure would grow by about 38 percent, compared to the budgeted increase of almost 80 percent, as the authorities intend to implement about 70 percent of the budgeted amount. All in all, public expenditure would increase by about 40 percent. Although both the overall and the non-oil balances are projected to strengthen, the non-oil deficit in percent of non-oil GDP will widen further.

\section{The authorities are taking steps to reduce the impact of the rapid growth of} expenditure on its quality and inflation. They noted that much of the inflationary pressures are due to the rise in imports prices. Nonetheless, they are concerned about the pace of the recent acceleration in prices and have formed a ministerial committee to monitor the situation and take policy actions. In addition to the ongoing rationalization of capital outlays, close attention is being accorded to sequencing. Some large projects are being postponed and competition among suppliers is being boosted by enhancing the regulations governing agency. In addition, in order to enhance efficiency, public-private partnerships (PPPs) are also being considered for utilities and other projects. Furthermore, on-lending by SCIs is being curbed by limiting their access to budget financing. 
15. The authorities are determined to move ahead with the WDP in order to enhance equity and the delivery of public services. ${ }^{6}$ They were aware of its potential risks for inflation and, if not implemented carefully, its effectiveness in achieving its intended goals. While they are still working out its details, they intend to ensure that its design addresses these risks. Assuming that WDP's transfers remain (as a percent of GDP) at their approved 2008 level and that the plan to limit the growth of other public outlays continues to be implemented, Libya's fiscal position will remain sustainable (Box 3).

\section{The authorities intend to ensure that the LIA's regulatory framework meets} high transparency and operational standards. The state budget will continue to be based on conservative oil price assumptions ${ }^{7}$ and the realized surpluses will be allocated to the LIA. Transfers from the LIA to the budget will not exceed its profit. Recent enhancements in the LIA's operational framework limited its domestic investments to the oil sector and instated specific auditing and publication requirements.

\section{Monetary Policy and Financial Sector Reform}

\section{The CBL has redoubled its efforts to enhance the monetary policy framework} and tighten monetary conditions. It introduced its own certificates of deposit, with Fund technical assistance, in May 2008. The policy interest rates were raised by 50 basis points, and the reserves requirement increased from 15 percent to 20 percent. The CBL is also embarking on a substantial technical cooperation program with the Fund to modernize its structure and enhance the payments system, with a view to improving its ability to conduct monetary policy.

18. Efforts are ongoing to further strengthen bank supervision. In particular, off-site surveillance techniques are being improved and methodologies to calculate capital adequacy measures are being modernized. The authorities also intend to strengthen CBL's supervision of SCIs. Regarding the AML/CFT, an amended law is being drafted to explicitly criminalize the financing of terrorism.

19. The authorities continue to advance financial sector reforms. They indicated that the recent progress in bank reforms and opening the market to foreign banks have laid the foundation for a competitive banking system. They intend to privatize the remaining two public commercial banks through the newly established stock market. They are also considering contracting international consultants to design an action plan to reform the SCIs.

\footnotetext{
${ }^{6}$ The WDP aims at improving the delivery of public services through replacing several ministries with smaller administrative bodies and transferring of the ownership and management of a large number of public entities to the population.

${ }^{7}$ These assumptions were $\$ 35$ and $\$ 65$ per barrel for 2007 and 2008, respectively.
} 


\section{Box 3. Fiscal Sustainability}

To assess fiscal sustainability, staff conducted an analysis using a permanent income approach that aims at ensuring intergenerational equity (Barnett and Ossowski 2002). According to this approach, annual public expenditure should not exceed the implicit return on government wealth. This means that the non-hydrocarbon deficit should be smaller than or equal to the returns on the government's net worth. To maintain intergenerational equity, population growth is taken into account. The analysis assumes a hydrocarbon production profile that would deplete proven reserves by 2070 . The extraction rate is based on the authorities' announced plans for the medium term.

The results show that Libya's fiscal position is sustainable based on current policies. However, the analysis is sensitive to changes in oil prices and to the implicit rate of return. For example, a drop in oil prices to about $\$ 80$ per barrel, while maintaining spending at the same level, would render the medium-term fiscal position unsustainable. Fiscal sustainability would also be challenged should the implicit rate of return decline by more than one percentage point (from the baseline assumption of 5 percent).

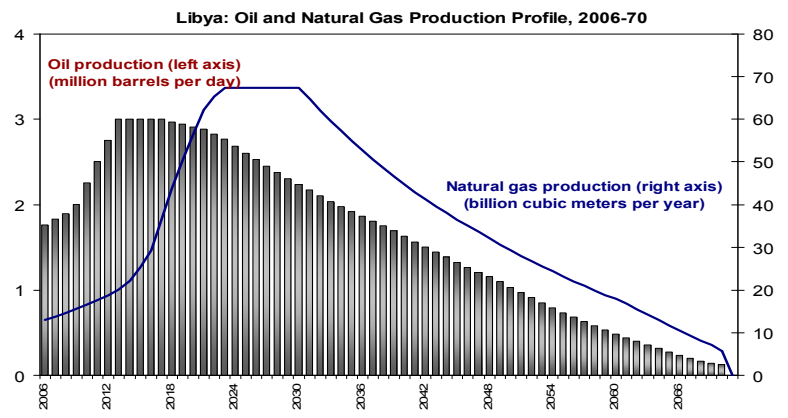

\begin{tabular}{|c|c|c|c|c|c|c|}
\hline & 2007 & 2008 & 2009 & 2010 & 2011 & 20122013 \\
\hline \multicolumn{7}{|l|}{ Estimated sustainable NHPD } \\
\hline Low (US \$60 per pb) & 177.7 & 142.8 & 119.2 & 104.1 & 92.6 & 83.675 .8 \\
\hline Medium(US \$ 80 pb) & 208.2 & 167.3 & 139.6 & 122.0 & 108.5 & $97.9 \quad 88.8$ \\
\hline High (US \$ 100 pb) & 237.9 & 191.2 & 159.6 & 139.4 & 124.0 & 111.9101 .5 \\
\hline Staff projections for NHPD & 135.9 & 155.8 & 138.2 & 117.7 & 109.8 & 103.896 .8 \\
\hline WE0 oil price (US \$ pb) & 71.1 & 116.5 & 125.0 & 123.5 & 123.5 & 123.5123 .8 \\
\hline Libya oil price (US Spb) & 69.1 & 113.2 & 121.5 & 120.0 & 120.0 & 120.0120 .3 \\
\hline Crude oil export unit value (2007 USS pb) & 69.1 & 111.0 & 116.8 & 113.1 & 110.9 & 108.7106 .8 \\
\hline
\end{tabular}
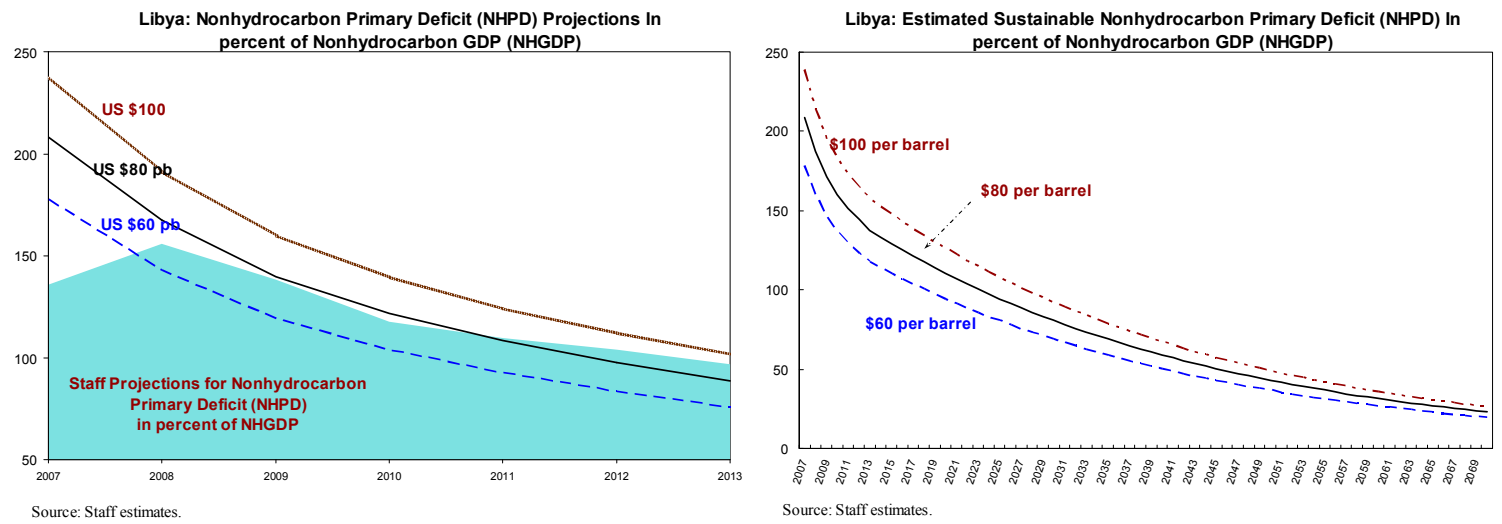

Given the uncertainty regarding future oil prices and rate of returns, the above analysis calls for caution. The fiscal position needs to be assessed periodically in line with any significant changes in the outlook. The fiscal stance also needs to be considered in line with developments in inflation. Implementation capacity is also an important factor in determining the appropriate pace of expenditure growth and its sectoral distribution. The World Bank is currently conducting a public expenditure review that should provide useful guidance in these areas. 


\section{External Sector Issues}

20. Staff's estimates suggest that the dinar is moderately undervalued (Box 4). The estimated undervaluation is, however, within the margin of error associated with this type of analysis. Furthermore, this undervaluation is likely to be transitional in view of the fiscal and current account projections that are based on current policies. The ongoing appreciation of the dinar in real effective terms is already capturing part of the improvement in fundamentals, and the current account surplus is projected to moderate over the medium term in line with import growth and the projected stabilization in oil prices.

21. The SDR continues to be an appropriate peg for the Libyan dinar. While most of Libya's imports originate in the euro area, oil (which constitutes more than 95 percent of Libya's exports) is priced in dollars. Furthermore, the SDR offers the advantage of being a transparent and straight-forward basket that is not vulnerable to pressure for change based on short-term developments in the world economy or Libya's trading pattern.

\section{E. Structural Reforms and Other Issues}

22. Progress has been made on various structural reforms, partly in line with past Fund TA recommendations and the Medium-Term Reform Strategy (CR/06/137). A sound framework for the management of the oil wealth has been established through the creation of the LIA; customs administration has been reformed and a large taxpayer's office established; the presentation of the budget has been consolidated and a macrofiscal unit initiated; a large number of public enterprises have been privatized; and one third of public employees are being retrenched to the private sector.

\section{Some progress has been made in implementing reforms aimed at achieving} greater regional integration and liberalizing trade. Harmonization of financial regulations, statistical frameworks, and payment and settlement systems with other Maghreb countries is ongoing. Certification requirements for trade with these countries have also been simplified. However, while customs duties on virtually all imports have been eliminated, imports-specific production and consumption taxes, in addition to a flat 4 percent "service" fee, are in place. Furthermore, ear-marked fees on imports, albeit small, have been recently introduced. Nonetheless, the effective rate of import taxation remains very low (less than 3 percent) due to extensive exemptions.

24. Libya's debt relief to heavily indebted poor countries (HIPCs) continues to be based on forgiving interest payments and using a combination of swaps and rescheduling of principal. The authorities indicated that agreements based on these modalities have already been reached with some HIPCs, and that negotiations are ongoing with others. 


\section{Box 4. Exchange Rate Assessment}

Staff's econometric estimates suggest that the dinar is moderately undervalued, but this may be a transitory phenomenon. Using the equilibrium real exchange rate (ERER) approach, ${ }^{1}$ the results indicate an undervaluation in the range of 15-20 percent at end2007. Since then, however, the dinar has appreciated by about 5 percent in real effective terms. It should be noted that this estimated range of undervaluation could be within the usually high error range associated with these exercises, which is due to data and methodological shortcomings. The latter is particularly relevant in oil developing countries, for which the appropriate analytical framework is still evolving.

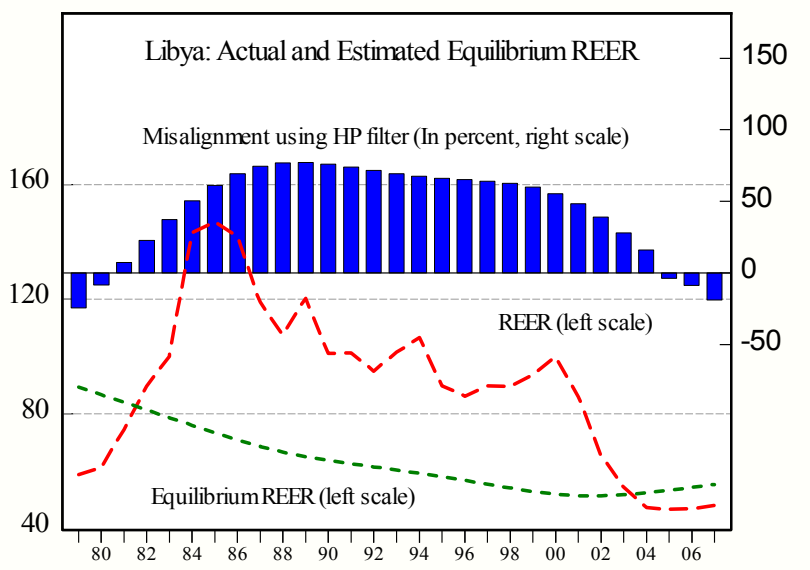

The above results are confirmed by another exercise that estimates the external current account "norm." ${ }^{2}$ The results indicate that Libya's external current account surplus is at present above its norm, implying an undervaluation of the exchange rate. However, the current account surplus is projected to decline steadily toward the norm over the medium term, with the continued increase in imports and the stabilization of oil prices.

The results need to be interpreted with caution. These projections are sensitive to

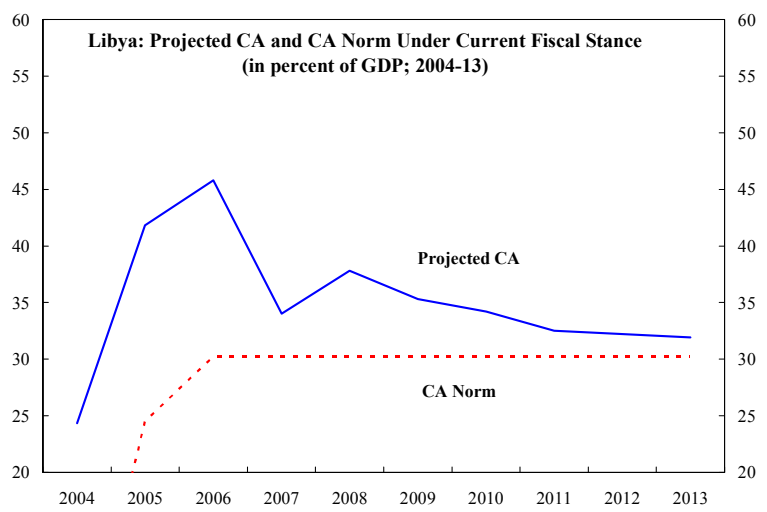
assumptions on future oil prices and public expenditure (and thus import) growth. Should oil prices decline below the current high projections or the efforts to rationalize the large expenditure plans waver, revised current account projections could converge to the norm earlier in the medium term.

1“Methodology for CGER Exchange Rate Assessments," IMF, November 2006 (www.imf.org/external/np/pp/eng/2006/110806.pdf). The equilibrium REER was estimated by a vector errorcorrection model in which the following set of fundamentals were the determining variables: terms of trade, public consumption as a percent of GDP, per capita income relative to trading partners, and net foreign assets as a percent of GDP.

${ }^{2}$ Data for eight countries (the GCC countries, Algeria, and Libya) were used to estimate the current account norm based on the following set of fundamentals: the fiscal balance, net foreign assets, the external oil balance, real per capita GDP growth, and population growth. 
25. Progress has been made in improving economic and financial statistics. National accounts and price statistics have been recently strengthened. The quality and timeliness of macroeconomic data have also been improved over the past few years. Further enhancing the compilation and quality of data continues to be hampered by insufficient coordination between different government agencies and staffing limitations.

\section{Staff Appraisal}

26. Libya's economy has performed strongly in recent years, benefiting from a favorable external environment and ongoing reforms. Growth remained buoyant, reflecting higher international oil prices and continued strong expansion of the nonhydrocarbon sectors. The fiscal and external current accounts registered large surpluses, and CBL's net foreign assets are accumulating rapidly. Inflation has, however, accelerated owing mainly to the increase in food prices and public expenditure.

27. Efforts to contain inflation should focus on tightening the fiscal stance by limiting the rapid increase in public expenditure, which is also posing significant risks for expenditure quality. While such increase appears affordable under current oil prices, it has contributed to a substantial rise in the non-oil fiscal deficit in relation to the non-hydrocarbon GDP. Although upgrading the infrastructure is essential to expand growth potential, it is important to continue to prioritize public investment. Scaling back more of the planned projects may be necessary, especially if inflation does not decline. It is also critical to adhere to the plan to limit any further increases in public wages and complete the civil service reform. Public financial management also needs to be further improved, including by unifying the process of budget preparation and implementation under the Ministry of Finance, and ensuring that the macrofiscal unit is enabled to fully perform its role.

\section{Staff welcomes the authorities' decision to limit the scope of the WDP in 2008} and urges them to maintain this approach in the period ahead. A less cautious approach would substantially increase the risk of crowding-out priority spending, encourage rentseeking activities, and significantly contribute to further inflationary pressures. Larger transfers to the population in the context of a full-fledged WDP would likely be mostly channeled to consumption or inefficient investments. This would not be the best way to utilize revenue from exhaustible resources and would jeopardize intergenerational equity. While revamping public administration in the context of the WDP presents an opportunity to address inefficiencies, if not done properly, it can pose serious risks for the delivery of essential public services. Staff, therefore, urges the authorities to carefully consider such plans in close consultation with the World Bank.

29. It is encouraging that the LIA has been launched in a transparent fashion and that its operational framework has been enhanced. In this connection, it would be important not to grant exceptions to the rules restricting domestic investments by the LIA, as such investments should be limited to what is envisaged in the state budget. Ensuring that the 
LIA invests exclusively abroad on a commercial basis would best serve its core objective of protecting Libya's savings for present and future generations. This would also avoid complicating the macroeconomic management of the domestic economy. Staff encourages the authorities to continue to enhance the operational framework of the LIA in line with the evolving best practices for sovereign wealth funds.

30. Staff welcomes CBL's recent efforts to reduce excess liquidity. While the scope for monetary policy is limited by the pegged exchange rate regime, there is a clear margin for further tightening especially in view of the largely negative interest rates. The recent increase in the CBL policy rates is, therefore, a step in the right direction. The increase in the reserves requirement will also contribute to these efforts, although greater reliance on indirect monetary policy instruments would be beneficial. It is also encouraging that lending by SCIs is being curbed by limiting their access to budget financing.

\section{The recent introduction of CBL's certificates of deposit is an important step} toward enhancing the monetary policy framework. Ongoing efforts to restructure the CBL and enhance the payments system would also help improve the effectiveness of indirect monetary policy instruments. The success of CBL's efforts to enhance monetary policy management will, however, remain contingent on close coordination with fiscal policy to limit the injection of liquidity, including by the SCIs.

32. Staff welcomes the ongoing strengthening of banking supervision, including by improving off-site surveillance techniques. Supervision would benefit further from enhanced coordination between the off-site and on-site units as well as capacity building through additional staffing and training. It is also crucial to bring the SCIs under CBL's full supervision to protect the quality of their assets. The fact that SCIs are currently subject to less stringent supervision than commercial banks could contribute to the dissemination of risky lending practices. The rapid pace at which they have been expanding soft loans and their very low cost of funding have contributed to the depressed lending and deposit rates in the financial system in general. Unless this situation is addressed, it would lead to a deterioration in financial intermediation and hinder the development of the banking system. It would also be important to develop modern regulatory and supervisory frameworks for the insurance sector and the newly-established stock market.

33. The steady progress made in bank privatization is encouraging. Ensuring a leveled playing field between the commercial banks and the SCIs, as well as continuing to open the market to foreign banks, would help establish a competitive banking sector that can support non-oil growth and job creation. In this connection, it would be useful to finalize the plans to privatize the two remaining public commercial banks and to establish an independent bank restructuring agency that would take over ownership of the SCIs and oversee their restructuring and privatization. 
34. The dinar's peg to the SDR has served the economy well. This arrangement provides a strong monetary anchor, while allowing some flexibility in the dinar's exchange rate vis-à-vis individual major currencies. The dinar appears to be moderately undervalued, but this is likely to be a transitory phenomenon in view of the projected decline in the current account surplus. An eventual move to greater exchange rate flexibility would be beneficial but would need to be gradual and preceded by a switch to market-based monetary management and the development of expertise in foreign exchange markets.

35. Staff encourages the authorities to make further progress in implementing structural reforms. In this regard, it would be crucial to enhance the regulatory environment, including to support the ongoing effort to implement part of Libya's ambitious investment program in the context of PPP arrangements within adequate safeguards. Building on the progress achieved in simplifying the customs regime would also be important. In this connection, the mission encourages the authorities to eliminate the service fee imposed on imports, as well as import-specific consumption and production taxes and ear-marked fees.

36. Staff encourages the authorities to provide full debt relief to heavily indebted poor countries in line with the HIPC Initiative.

37. While data provision is adequate for surveillance, the authorities are encouraged to continue to improve economic and financial statistics in order to facilitate better monitoring and analysis of developments to guide policy formulation.

38. It is proposed that the next Article IV consultation with Libya take place on the standard 12-month cycle. 
Table 1. Libya: Basic Economic and Financial Indicators, 2004-08

\begin{tabular}{|c|c|c|c|c|c|}
\hline & 2004 & 2005 & 2006 & $\begin{array}{c}\text { Prel. } \\
2007\end{array}$ & Proj. \\
\hline & \multicolumn{5}{|c|}{ (Annual percentage change, unless otherwise specified) } \\
\hline \multicolumn{6}{|l|}{ National income and prices } \\
\hline Real GDP & 6.0 & 9.9 & 5.9 & 6.8 & 7.1 \\
\hline Nonhydrocarbons & 6.8 & 13.6 & 7.9 & 10.3 & 11.0 \\
\hline Hydrocarbons & 5.5 & 7.2 & 4.3 & 3.9 & 3.8 \\
\hline Nominal GDP in billions of Libyan Dinars & 43.4 & 59.5 & 72.3 & 88.1 & 141.7 \\
\hline Nominal GDP in billions of U.S. dollars & 33.3 & 45.5 & 55.1 & 69.9 & 115.8 \\
\hline Per capita GDP in thousands of U.S. dollars & 5.8 & 7.8 & 9.2 & 11.5 & 18.7 \\
\hline $\mathrm{CPI}$ inflation (average) & 1.0 & 2.9 & 1.4 & 6.2 & 12.0 \\
\hline \multirow[t]{2}{*}{ CPI inflation (e-o-p) 1/ } & -3.5 & 9.8 & 2.8 & 7.3 & 11.8 \\
\hline & \multicolumn{5}{|c|}{ (In percent of GDP) } \\
\hline \multicolumn{6}{|l|}{ Central government finances } \\
\hline Revenue & 53.6 & 62.9 & 65.1 & 61.4 & 66.3 \\
\hline Of which: Hydrocarbon & 46.4 & 58.5 & 60.2 & 55.2 & 60.9 \\
\hline Expenditure and net lending & 39.7 & 32.1 & 29.5 & 35.2 & 31.4 \\
\hline Of which: capital expenditure & 16.2 & 18.2 & 16.2 & 21.0 & 18.0 \\
\hline Overall position (deficit -) & 13.9 & 30.9 & 35.5 & 26.2 & 35.0 \\
\hline Non-oil deficit & -32.5 & -27.6 & -24.7 & -29.0 & -25.9 \\
\hline \multirow[t]{2}{*}{ Non-oil deficit (in percent of non-oil GDP) } & -111.9 & -123.7 & -127.6 & -135.9 & -155.8 \\
\hline & \multicolumn{5}{|c|}{ (Changes as a percent of beginning of the year money stock) } \\
\hline \multicolumn{6}{|c|}{ 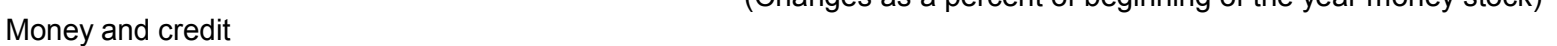 } \\
\hline Money and quasi-money & 13.3 & 30.6 & 15.3 & 40.8 & 40.0 \\
\hline Net credit to the government & -106.5 & -115.5 & -115.9 & -52.3 & -106.3 \\
\hline Credit to the economy & -0.8 & 4.9 & 5.7 & 6.9 & 8.5 \\
\hline Of which: Credit to the private sector & 1.2 & 0.9 & 0.9 & 2.6 & 3.0 \\
\hline \multirow[t]{2}{*}{ Deposit rate (1-year deposits, in percent) $1 /$} & 4.5 & 4.5 & 4.5 & 4.5 & 4.5 \\
\hline & \multicolumn{5}{|c|}{ (In billions of U.S. dollars; unless otherwise indicated) } \\
\hline \multicolumn{6}{|l|}{ Balance of payments } \\
\hline Exports, f.o.b. & 20.4 & 31.4 & 39.2 & 44.5 & 73.6 \\
\hline Of which: hydrocarbons & 19.5 & 30.5 & 38.2 & 43.4 & 72.3 \\
\hline Imports, f.o.b. & 8.8 & 11.2 & 13.1 & 17.4 & 23.0 \\
\hline Current account balance & 7.4 & 17.4 & 25.2 & 23.8 & 43.8 \\
\hline (As percent of GDP) & 22.3 & 38.4 & 45.8 & 34.0 & 37.8 \\
\hline Overall balance (deficit -) & 4.6 & 15.4 & 19.4 & 20.1 & 44.7 \\
\hline (As percent of GDP) & 13.9 & 33.9 & 35.2 & 28.7 & 38.6 \\
\hline \multicolumn{6}{|l|}{ Reserves } \\
\hline Net Foreign Assets of CBL & 25.9 & 39.3 & 58.7 & 78.8 & 123.5 \\
\hline Net international reserves & 16.2 & 23.0 & 27.9 & 35.7 & 43.6 \\
\hline In months of next year's imports & 14.4 & 17.4 & 16.2 & 15.7 & 15.0 \\
\hline \multicolumn{6}{|l|}{ Exchange rate } \\
\hline Official exchange rate (LD/US\$, period average) 2/ & 1.30 & 1.31 & 1.31 & 1.26 & 1.20 \\
\hline Official exchange rate (LD/US\$, end of period) $2 /$ & 1.24 & 1.35 & 1.28 & 1.22 & 1.20 \\
\hline Real effective exchange rate (percent change) $3 /$ & -8.50 & 9.11 & -3.14 & 0.40 & 5.53 \\
\hline Crude oil production (millions of barrels per day) & 1.62 & 1.69 & 1.76 & 1.83 & 1.90 \\
\hline Libyan crude oil price (US\$/bbl) & 36.9 & 51.9 & 62.5 & 69.1 & 113.2 \\
\hline \multicolumn{6}{|l|}{ Memorandum item: } \\
\hline Total loans disbursed by SCls (change in percent) & 25.0 & 135.0 & 53.0 & 36.0 & $\ldots$ \\
\hline
\end{tabular}

Sources: Libyan authorities; and Fund staff estimates and projections.

$1 /$ The 2008 data are for end-March.

2/ The 2008 data are for end-April.

3/ The 2008 data are for end-February. 
Table 2. Libya: Consolidated Fiscal Operations, 2004-08

\begin{tabular}{|c|c|c|c|c|c|c|c|}
\hline & 2004 & 2005 & 2006 & $\begin{array}{r}2007 \\
\text { Budget1/ }\end{array}$ & 2007 & $\begin{array}{r}2008 \\
\text { Budget1/ }\end{array}$ & $\begin{array}{l}2008 \\
\text { Proj. }\end{array}$ \\
\hline & \multicolumn{7}{|c|}{ (In millions of Libyan dinars) } \\
\hline Total Revenue & 23,272 & 37,413 & 47,088 & 32,244 & 54,114 & 51,623 & 93,979 \\
\hline Hydrocarbon & 20,141 & 34,764 & 43,566 & 24,016 & 48,639 & 43,656 & 86,250 \\
\hline Nonhydrocarbon & 3,131 & 2,650 & 3,523 & 8,229 & 5,475 & 7,967 & 7,729 \\
\hline Nonhydrocarbon Tax Revenue & 1,617 & 1,526 & 1,786 & 2,043 & 2,531 & 3,020 & 2,746 \\
\hline Taxes on income and profits & 309 & 397 & 691 & 1,115 & 1,376 & 2,169 & 1,726 \\
\hline Taxes on international trade & 602 & 517 & 527 & 400 & 528 & 600 & 722 \\
\hline Other taxes and fees & 705 & 611 & 569 & 528 & 627 & 251 & 298 \\
\hline Nontax Revenue 2/ & 1,222 & 873 & 1,464 & 6,186 & 2,714 & 4,947 & 4,697 \\
\hline of which: LIA & $\ldots$ & $\ldots$ & $\ldots$ & 1,580 & 1,438 & 3,000 & 3,097 \\
\hline GMR Revenue & 292 & 251 & 272 & 0 & 231 & 0 & 286 \\
\hline Total Expenditure & 17,230 & 19,060 & 21,377 & 32,245 & 31,018 & 51,623 & 44,438 \\
\hline Current expenditure & 10,195 & 8,245 & 9,693 & 13,074 & 12,511 & 18,556 & 18,988 \\
\hline Administrative budget & 6,505 & 8,146 & 8,988 & 13,074 & 12,511 & 18,556 & 18,988 \\
\hline Expenditure on goods and services & 5,541 & 6,649 & 7,424 & 11,067 & 10,414 & 10,481 & 11,021 \\
\hline Wages and salaries $3 /$ & 3,675 & 4,258 & 4,772 & 7,787 & 7,286 & 7,424 & 7,424 \\
\hline Other purchases of goods and services & 1,867 & 2,391 & 2,652 & 3,280 & 3,128 & 3,057 & 3,597 \\
\hline Subsidies and transfers & 964 & 1,497 & 1,564 & 2,007 & 2,097 & 8,074 & 7,967 \\
\hline Food Subsidies & 832 & 1,050 & 1,050 & 806 & 1,006 & 1,300 & 1,300 \\
\hline Wealth Distribution Program 3/ & $\ldots$ & $\cdots$ & $\ldots$ & $\ldots$ & $\ldots$ & 4,622 & 4,622 \\
\hline Other transfers & 132 & 447 & 514 & 1,201 & 1,091 & 2,152 & 2,044 \\
\hline Extrabudgetary current expenditure 4/ & 3,690 & 99 & 705 & 0 & 0 & 0 & 0 \\
\hline Errors and Omissions & 0 & 0 & 0 & 0 & 0 & 0 & 0 \\
\hline Capital expenditure & 7,035 & 10,815 & 11,685 & 19,170 & 18,506 & 33,067 & 25,450 \\
\hline Development budget & 6,135 & 7,570 & 10,079 & 14,367 & 12,137 & 33,067 & 20,297 \\
\hline Extrabudgetary capital expenditure & 798 & 825 & 1,026 & 3,903 & 4,134 & 0 & 3,653 \\
\hline Net lending & 102 & 2,420 & 580 & 900 & 2,235 & 0 & 1,500 \\
\hline Overall balance & 6,042 & 18,353 & 25,711 & 0 & 23,096 & 0 & 49,541 \\
\hline Nonhydrocarbon balance & $-14,099$ & $-16,410$ & $-17,855$ & $-24,016$ & $-25,543$ & $-43,656$ & $-36,709$ \\
\hline Domestic Financing & $-6,042$ & $-18,353$ & $-25,711$ & 0 & $-23,096$ & 0 & $-49,541$ \\
\hline Banking system & $-6,654$ & $-14,426$ & $-20,675$ & 0 & $-10,917$ & 0 & $-31,541$ \\
\hline \multirow[t]{2}{*}{ Nonbank financing } & 612 & $-3,928$ & $-5,036$ & 0 & $-12,180$ & 0 & $-18,000$ \\
\hline & \multicolumn{7}{|c|}{ ( In percent of GDP ) } \\
\hline Total Revenue & 53.6 & 62.9 & 65.1 & 36.6 & 61.4 & 36.4 & 66.3 \\
\hline Hydrocarbon & 46.4 & 58.5 & 60.2 & 27.3 & 55.2 & 30.8 & 60.9 \\
\hline Nonhydrocarbon & 7.2 & 4.5 & 4.9 & 9.3 & 6.2 & 5.6 & 5.5 \\
\hline Total Expenditure & 39.7 & 32.1 & 29.5 & 36.6 & 35.2 & 36.4 & 31.4 \\
\hline Current expenditure & 23.5 & 13.9 & 13.4 & 14.8 & 14.2 & 13.1 & 13.4 \\
\hline Wage and salaries & 8.5 & 7.2 & 6.6 & 8.8 & 8.3 & 5.2 & 5.2 \\
\hline Subsidies and transfers & 2.2 & 2.5 & 2.2 & 2.3 & 2.4 & 5.7 & 5.6 \\
\hline Capital expenditure & 16.2 & 18.2 & 16.2 & 21.8 & 21.0 & 23.3 & 18.0 \\
\hline Overall balance & 13.9 & 30.9 & 35.5 & 0.0 & 26.2 & 0.0 & 35.0 \\
\hline
\end{tabular}

Sources: Ministry of Finance; and Fund staff estimates and projections.

1/ The budget totals include a 5 percent earmarked for pension and other transfers.

2/ For 2007 budget includes million LD 3200 carried over from 2006 budget.

3/ For 2008 severance payments of million LD 1050 for employees being retrenched are included in the Wealth Distribution

4/ For 2004, includes Lockerbie settlements of LD 1,404 million from the oil reserve fund. 
Table 3. Libya: Monetary Survey, 2004-08

\begin{tabular}{|c|c|c|c|c|c|c|}
\hline & 2004 & 2005 & 2006 & 2007 & $\begin{array}{r}2008 \\
\text { March }\end{array}$ & $\begin{array}{l}2008 \\
\text { Proj. }\end{array}$ \\
\hline & \multicolumn{6}{|c|}{ (In millions of Libyan dinars) } \\
\hline Net foreign assets & 34,237 & 56,422 & 79,433 & 100,516 & 105972 & 140,562 \\
\hline Central bank & 33,066 & 54,448 & 77,241 & 98,309 & 103404 & 137,934 \\
\hline Foreign assets & 33,073 & 54,460 & 77,253 & 98,326 & 103418 & 137,954 \\
\hline Foreign liabilities & 7 & 12 & 13 & 17 & 14 & 20 \\
\hline Deposit money banks & 1,171 & 1,974 & 2,193 & 2,206 & 2568 & 2,628 \\
\hline Foreign assets & 1,312 & 2,046 & 2,297 & 2,457 & 2860 & 2,958 \\
\hline Foreign liabilities & 141 & 72 & 105 & 250 & 293 & 329 \\
\hline Net domestic assets & $-17,402$ & $-38,149$ & $-58,374$ & $-70,835$ & -75946 & $-99,040$ \\
\hline Domestic credit & $-9,762$ & $-25,237$ & $-45,362$ & $-54,927$ & -60670 & $-83,997$ \\
\hline Net claims on government & $-17,973$ & $-34,137$ & $-55,308$ & $-66,316$ & -72804 & $-97,858$ \\
\hline Central bank claims & 828 & 828 & 2,560 & 3,163 & 9182 & 9,489 \\
\hline Government deposits with central bank & 18,028 & 34,112 & 56,329 & 68,940 & 81487 & 106,767 \\
\hline Commercial banks' claims & 373 & 373 & 373 & 328 & 328 & 328 \\
\hline Governments' deposits with commercial banks & 1,147 & 1,227 & 1,912 & 868 & 826 & 908 \\
\hline Claims on the rest of the economy & 8,212 & 8,900 & 9,946 & 11,389 & 12134 & 13,945 \\
\hline Claims on nonfinancial public enterprise & 3,477 & 4,271 & 5,128 & 6,019 & 6589 & 7,674 \\
\hline Claims on the private sector & 4,452 & 4,576 & 4,742 & 5,286 & 5463 & 6,186 \\
\hline Claims on specialized banking institutions & 67 & 45 & 68 & 76 & 70 & 76 \\
\hline Claims on nonbank financial institutions & 215 & 7 & 7 & 8 & 12 & 8 \\
\hline Other items (net) & $-7,640$ & $-12,912$ & $-13,012$ & $-15,908$ & -15276 & $-15,043$ \\
\hline Broad money & 13,992 & 18,273 & 21,059 & 29,659 & 30026 & 41,522 \\
\hline Money & 10,537 & 14,028 & 16,343 & 22,837 & 23187 & 31,889 \\
\hline Currency in circulation & 2,613 & 3,309 & 3,933 & 4,581 & 4969 & 5,605 \\
\hline Demand deposits & 7,924 & 10,719 & 12,410 & 18,256 & 18218 & 26,284 \\
\hline Quasi-money & 3,455 & 4,245 & 4,716 & 6,821 & 6840 & 9,633 \\
\hline \multicolumn{7}{|l|}{ Memorandum items: } \\
\hline \multirow[t]{2}{*}{ Net claims on the government } & $-17,447$ & $-33,364$ & $-54,038$ & $-64,955$ & -72583 & $-96,496$ \\
\hline & \multicolumn{6}{|c|}{ (Change in percent) } \\
\hline Broad money & 13.3 & 30.6 & 15.3 & 40.8 & 41.7 & 40.0 \\
\hline Money & 16.7 & 33.1 & 16.5 & 39.7 & 42.3 & 39.6 \\
\hline Quasi-money & 4.1 & 22.8 & 11.1 & 44.6 & 39.6 & 41.2 \\
\hline Net claims on government & -272.9 & -89.9 & -62.0 & -19.9 & -17.1 & -47.6 \\
\hline Claims on the economy & -1.1 & 8.4 & 11.7 & 14.5 & 16.9 & 22.4 \\
\hline Claims on nonfinancial public enterprises & -8.1 & 22.8 & 20.1 & 17.4 & 21.3 & 27.5 \\
\hline \multirow[t]{2}{*}{ Claims on the private sector } & 3.6 & 2.8 & 3.6 & 11.5 & 12.1 & 17.0 \\
\hline & \multicolumn{6}{|c|}{ (Percent change over beginning broad money stock) } \\
\hline Net foreign assets & 57.6 & 158.6 & 125.9 & 100.0 & 18.4 & 135.1 \\
\hline Domestic credit & -107.3 & -110.6 & -110.1 & -45.4 & -19.4 & -98.0 \\
\hline Net claims on government & -106.5 & -115.5 & -115.9 & -52.3 & -21.9 & -106.3 \\
\hline Claims on the economy & -0.8 & 4.9 & 5.7 & 6.9 & 2.5 & 8.6 \\
\hline Claims on nonfinancial public enterprises & -2.5 & 5.7 & 4.7 & 4.2 & 1.9 & 5.6 \\
\hline Claims on the private sector & 1.2 & 0.9 & 0.9 & 2.6 & 0.6 & 3.0 \\
\hline
\end{tabular}

Sources: Central Bank of Libya; and staff projections. 


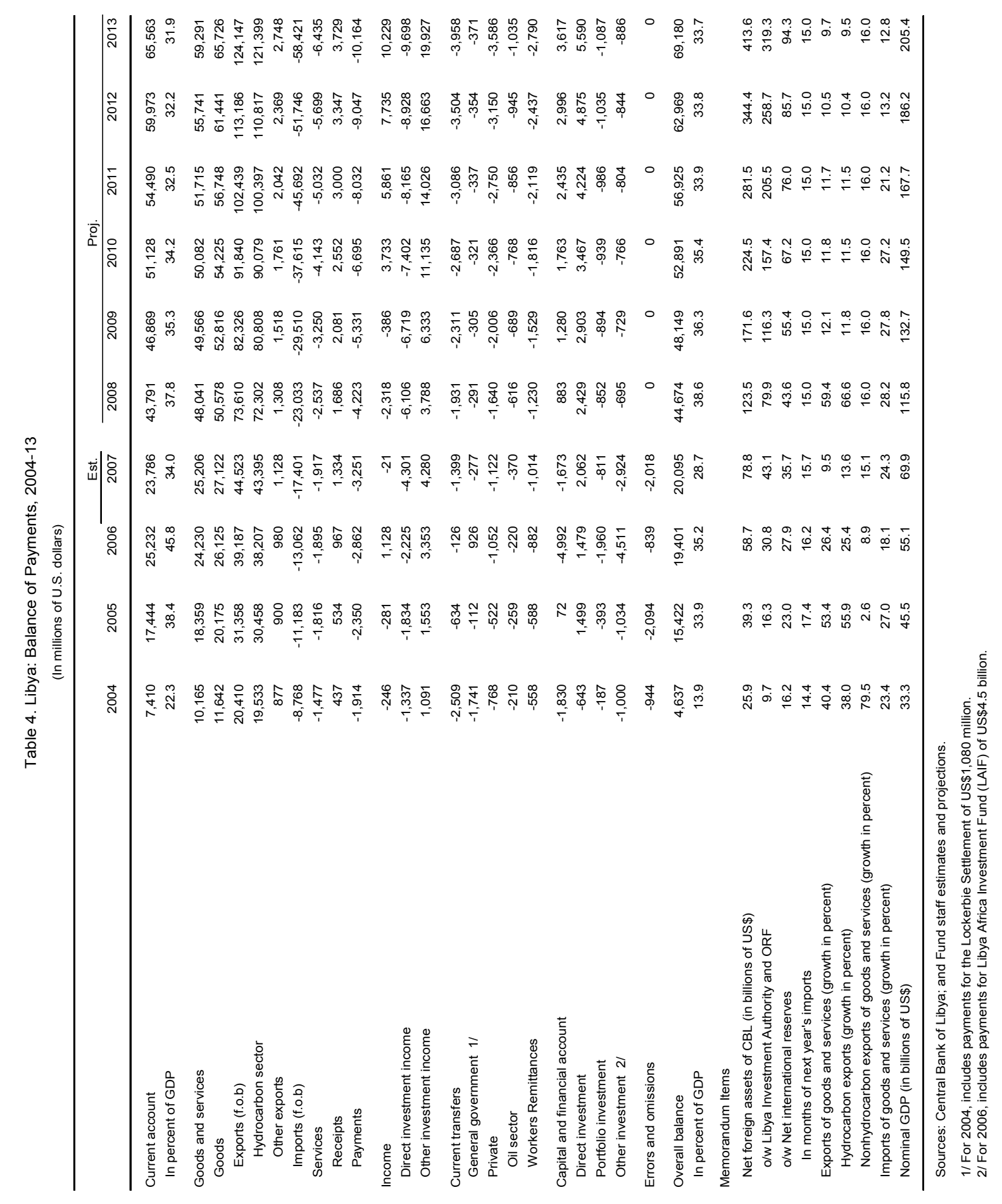




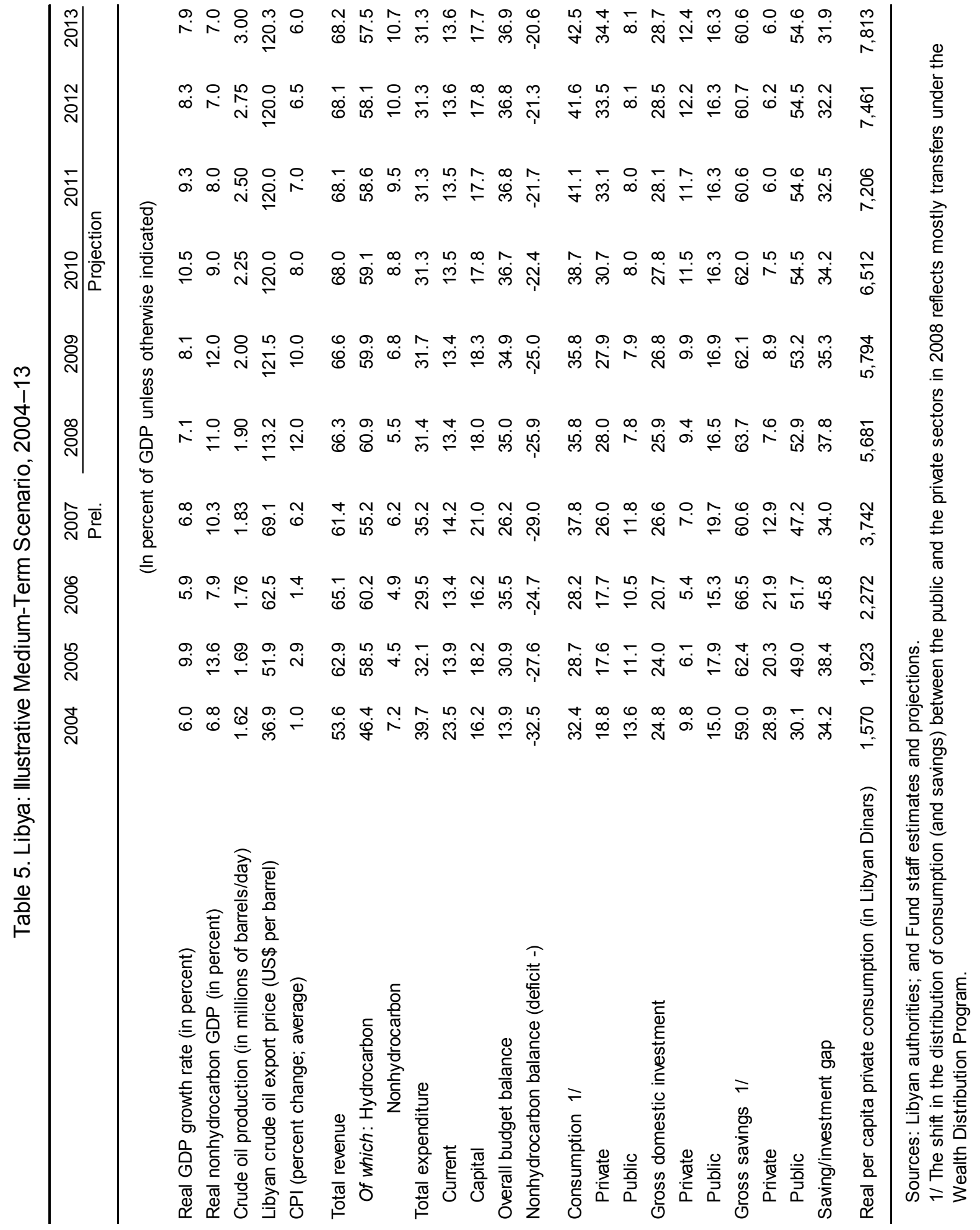


Table 6. Libya: Financial Soundness Indicators, 2002-07

\begin{tabular}{|c|c|c|c|c|c|c|}
\hline & 2002 & 2003 & 2004 & 2005 & 2006 & 2007 \\
\hline \multicolumn{7}{|l|}{ Core set: } \\
\hline Regulatory capital to risk-weighted assets & 13.8 & 15.1 & 18.6 & 19.1 & 17.2 & 15.6 \\
\hline Nonperforming loans net of provisions to capital & 93.6 & 102.3 & 137.9 & 76.2 & 57.3 & 50.2 \\
\hline Nonperforming loans to gross loans & 27.8 & 28.4 & 35.5 & 32.0 & 25.4 & 24.9 \\
\hline Return on assets & 0.4 & 0.4 & 0.4 & 0.4 & 0.5 & 0.4 \\
\hline Return on equity & 6.9 & 6.2 & 6.4 & 7.4 & 7.9 & 8.0 \\
\hline Liquid assets to total assets & 24.9 & 27.8 & 46.2 & 56.8 & 57.9 & 66.5 \\
\hline Liquid assets to short-term liabilities & 53.0 & 62.0 & 92.4 & 107.6 & 104.3 & 117.2 \\
\hline Net open position in foreign exchange to capital and reserves & 85.6 & 61.7 & 129.1 & 170.9 & 175.0 & 127.6 \\
\hline \multicolumn{7}{|l|}{ Encouraged set: } \\
\hline Capital to assets & 6.0 & 6.1 & 5.5 & 5.8 & 5.3 & 5.4 \\
\hline Foreign-currency-denominated assets to total assets & 0.3 & 0.2 & 0.1 & 0.1 & 0.2 & 0.3 \\
\hline Loan provisions to nonperforming loans & 61.1 & 59.4 & 51.8 & 61.1 & 69.0 & 66.0 \\
\hline Ratio of banks' lending to banks' capital & 845.6 & 854.8 & 773.4 & 586.7 & 512.2 & 468.1 \\
\hline
\end{tabular}

Source: Central Bank of Libya.

1/ Financial soundness indicators need to be interpreted with caution due to remaining deficiencies in banks' implementation of International Financial Reporting Standards. 


\section{INTERNATIONAL MONETARY FUND}

SOCIALIST PEOPLE’S LIBYAN ARAB JAMAHIRIYA

\section{Article IV Consultation}

\section{Informational Annex}

Prepared by the Middle East and Central Asia Department

(in consultation with other departments)

July 3, 2008

Contents

Page

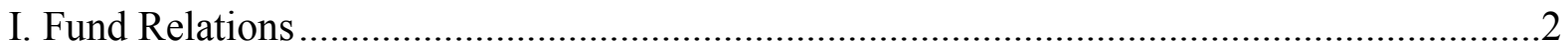

II. Relations with the World Bank Group .......................................................................4

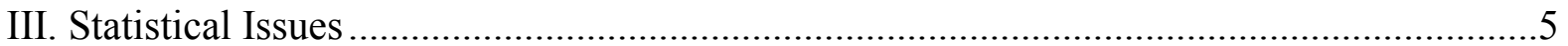


ANNEX I. LIBYA: FUND RELATIONS

(As of May 31, 2008)

I. Membership Status: Joined 09/17/58; Article VIII

II. General Resources Account:

SDR Million

Quota

$1,123.70$

Fund holdings of currency

728.20

Percent of Quota

Reserve position in Fund

395.51

100.00

64.80

35.20

III. SDR Department:

SDR Million

Net cumulative allocation

58.77

Percent of Allocation

Holdings

565.95

100.00

962.97

IV. Outstanding Purchases and Loans: None

V. Latest Financial Arrangements: None

VI. Projected Obligations to Fund: None

VII. Exchange Rate Arrangement:

On January 1, 2002, the authorities adopted a conventional fixed peg to the SDR at a rate of LD $1=$ SDR 0.608 . In June 2003, the exchange rate was devalued by 15 percent to LD $1=$ SDR 0.5175. From February 14, 1999 to December 31, 2001, a dual exchange rate system was in place, with an "official" exchange rate pegged to the SDR, and a "special" exchange rate pegged to the U.S. dollar.

\section{Exchange System:}

In June 2003, the authorities eliminated the restrictions that gave rise to multiple currency practices. Libya accepted its obligations under Article VIII, Sections 2(a), 3, and 4 of the Articles of Agreement in June 2003.

\section{Article IV Consultation:}

Libya is on a 12-month consultation cycle. The last Article IV staff report (CR/07/149) was discussed by the Executive Board in April 2007.

\section{Technical Assistance:}

1. August 2001: MAE mission in monetary operations, banking supervision, and payment system.

2. December 2003: Two-week course on financial programming (INS and MCD).

3. February 2004: FAD mission on strengthening tax policy and revenue administration. 
4. May 2004: MFD mission on monetary policy operations and introduction of financial instruments and markets.

5. June 2005: MFD mission on financial sector reform including bank restructuring.

6. June 2005: STA multisector mission on government finance statistics (GFS) and national accounts statistics (first part).

7. July 2005: FAD mission on reform of tax and customs directorates.

8. August/September 2005: STA multisector statistics on monetary and balance of payments statistics (second part).

9. Missions by Middle East Technical Assistance Centre (METAC) on banking supervision (May, July, August, and September 2005)

10. April 2006: FAD mission on Public Financial Management Reform.

11. June 2006: Posting of a long-term resident advisor on national accounts.

12. Two missions by METAC on banking supervision (May and August 2006).

13. Two follow-up missions by METAC on tax administration reform (August and December 2006).

14. October/November 2006: MCM and LEG mission to complete the standard review of the foreign exchange system under the Fund's Article VIII.

15. February 2007: A METAC follow-up mission on balance of payments statistics.

16. February/March 2007: Preliminary MCM mission on modernization and restructuring of the Central Bank of Libya.

17. March 2007: Two METAC missions on review of consumer price index statistics, and establishing producer price statistics, respectively.

18. July 2007: MCM mission on Sovereign Asset and Reserve Management, Monetary Policy Operations and Central Bank Accounting and Auditing.

19. November 2007: MCM mission on modernization and restructuring of the Central Bank of Libya.

20. January/February 2008: A METAC follow-up mission on balance of payments statistics.

21. February/March 2008: MCM mission on monetary operations.

22. November 2007-April 2008: Three missions by METAC on banking supervision. 


\section{ANNEX II. LiBYA: Relations WiTh THE WORLD BANK GROUP \\ Prepared by the World Bank staff}

(As of June 17, 2008)

1. Libya has been a member of the World Bank Group since 1958, joining the International Bank of Reconstruction and Development (IBRD) and International Finance Corporation (IFC) in September 1958, International Development Association (IDA) in August 1961, and Multilateral International Guarantee Association (MIGA) in April 1993. There have been no World Bank Group loans made to Libya to date as the development of the country's petroleum assets from 1960 placed Libya among capital-surplus oil-producing countries, and provided resources to build extensive infrastructure and provide social services.

2. In 2007, a Technical Cooperation Agreement was signed between the Bank and the Government of Libya, with a total budget of $\$ 1$ million contributed jointly by the two parties. The Agreement funds a Joint Economic Advisory Program, geared to support and further Libya's reform process, covering the period of July 1, 2007 to June 30, 2008. Activities were launched in the areas of an Investment Climate Assessment, Business and Legal Environment, and support for the development of the Libya Vision 2025. A Public Expenditure Review (PER) was also launched in August 2007, with the main mission taking place in November 2007, and the completion of the document scheduled by October 2008. The PER benefits from inputs provided by IMF staff.

3. A Bank mission took place in March 2008 to introduce the new Director of the Maghreb Department to the Libyan authorities, and to discuss the proposed work program with the country. The authorities communicated their desire to proceed with the PER work, but that it should take into account recent developments (the March 2, 2008 decision by Khadafi to reorganize the government).

4. Two high-level workshops were held in April 2008. The first one was on "Libya in Transition." It covered the economic strategy, oil revenue management and social transfers. The second was on "Topics of Private Sector Development" and had an active participation from the private sector.

5. Several activities are planned for FY2009: a) Completion of the Public Expenditure Review; b) TA support on WTO accession, review of business regulations, and preparation of an Investment Climate Assessment. A review and update of the 2007-2008 Memorandum of Understanding (MOU) should also take place. A final new area of proposed collaboration includes TA on statistical capacity building and surveys. 


\section{ANNEX III. LIBYA: STATISTICAL ISSUES}

1. Data provision has some shortcomings, but is broadly adequate for surveillance. Weaknesses remain in the area of national accounts and the balance of payments, as well as (i) the conceptual and compilation procedures underpinning the collection of statistics in the various sectors; (ii) deficiencies in coverage, periodicity, and timeliness; (iii) lack of consistency of data across sectors; and (iv) with the exception of monetary data, lack of a reporting system to facilitate updating MCD's operational database between missions. These issues are compounded by institutional weaknesses, the lack of interagency cooperation, and the proliferation of agencies with unclearly demarked and often overlapping responsibilities.

2. A 2005 (June 4-9 and August 27-September 3) multisector mission examined the conceptual and compilation procedures for national accounts, price indices, foreign trade, money and banking, and government finance statistics. It developed recommendations for improvement in these systems, and encouraged Libya to expedite participation in the General Data Dissemination System (GDDS). The Middle East Regional Technical Assistance Center (METAC) prepared the metadata for the price and external sector that is needed for the participation in the GDDS. In February 2006, the authorities communicated their decision to use the GDDS as a framework for developing the statistical system and appointed a GDDS coordinator. To participate in the GDDS, the authorities should provide the Fund with the final metadata and prioritized plans for improving the statistical system.

\section{National accounts}

3. Some progress has been made in the compilation of GDP estimates by economic activity through 2004, based on the 1968 System of National Accounts. However, the compilation process is hampered by high staff turnover and significant delays in the receipt of basic data from various sources, particularly other government agencies. In addition, many of the surveys are outdated. Annual data up to 2002 were reported to STA in 2004 and published in the International Financial Statistics (IFS); however, the estimates are not fully consistent with other data sets. A new household survey was finalized in 2003.

4. To improve the national accounts, the 2005 STA mission made several recommendations including: (i) establishing a National Statistical Agency to produce and disseminate official statistics and coordinate the national statistical program; (ii) creating a National Statistical Council as a legally empowered interagency coordination committee to oversee compilation of national accounts statistics; (iii) transferring responsibility for the national accounts from the National Planning Council to the Census and Statistical Department of the National Information and Documentation Agency (NIDA) and creating 610 additional permanent staff positions; (iv) prioritizing implementation of the 1993 System of National Accounts and outlining entailed data requirements; (v) improving the questionnaires used for the construction and manufacturing surveys and the establishments frame; (vi) initiating regular surveys of major services, agricultural output, and public and 
private construction; and (vii) improving estimates for transport, storage, and communication companies (by including the three airline companies, shipping establishments, and telecommunication enterprises in the services sector), and for trade margin (by excluding margin of goods not channeled through wholesale or retail trade).

5. STA has appointed a resident national accounts statistics advisor to assist in implementing STA recommendations in particular, and to improve the national accounts in general. The assignment, which began in June 2006, was for one year and renewed for another year upon the request of the authorities. The advisor focused on identifying new data sources and establishing a system to collect the necessary data. He also coordinated the formation of several technical committees to guarantee that the data obtained by national accounts compilers are consistent with the data compiled by other agencies. The advisor concluded his work in June 2008 and the authorities produced revised national accounts statistics.

\section{Price statistics}

6. The CPI index is based on weights derived from the 1992-93 household budget survey, covers only Tripoli, has 1999 as reference year, and is compiled from 2000 onwards. A new index based on a 2003 household budget survey is compiled since 2007. Both of these indexes are available with a one-month lag and published on the Central Bank of Libya (CBL) website. A new household expenditure survey is being conducted between November 2007 and October 2008. The expenditure data will be used to update the CPI and further expand its geographic coverage to include eight urban and rural areas - Tripoli, Benghazi, Sebha, Ghiryan, Sert, El Jabal Al Akhadar, Meserati, and Zawya. The official index is now based on the 2003 household survey and an updated and expanded CPI is planned to be released in January 2010.

7. The 2005 STA mission had recommended that compilers should (i) expand the coverage of the new CPI to include Benghazi and Sabah in addition to Tripoli; (ii) align the classification system more closely with international standards (particularly by including services of owner-occupied dwellings and second-hand goods in the CPI); (iii) adjust seasonal items and temporarily missing items; (iv) revise all item descriptions and specify the brand name and country of origin to ensure accurate data collection; (v) replace the administrative data used to estimate rent by a sample of rental units; and (vi) develop the methodology for compiling a producer price index.

\section{Monetary and financial statistics}

8. While the timeliness and quality of monetary data reported for IFS have improved significantly, some methodological deficiencies remain. To enhance monetary and financial statistics, the STA missions in 2005 and 2007 made the following recommendations: (i) reclassify Libyan Foreign Bank (LFB) as a resident financial institution under other depository corporations and include LFB in the institutional coverage of the monetary 
survey; (ii) adopt market-based valuation of financial instruments and accrual accounting procedures for adding accruing interest to the outstanding amount of the instrument;

(iii) revalue CBL's holdings of monetary gold at end-period market prices; (iv) identify all Fund-related accounts in the CBL's balance sheet as per IMF Finance Department instructions; (v) when specialized credit institutions start issuing deposit liabilities, reclassify these institutions as other depository corporations and include them in the institutional coverage of the monetary survey; and (vi) revise/develop report forms for banks that would contain a breakdown of positions by currency of denomination, financial instrument, residency and economic sector of counterparty consistent with the structure of the Standardized Report Forms.

\section{Fiscal data}

9. The fiscal information system remains fragmented and inconsistent with international standards, since it was designed for administrative reporting under the government finance law, rather than for purposes of providing timely statistical information for economic planning and analysis. However, there has been significant improvement in this area. Monthly and quarterly data for key components of revenue and expenditure are being reported to staff on a regular basis.

10. To improve the fiscal data, the 2005 STA mission recommended: (i) adopting centralized management of all budgetary central government accounts at the ministry of finance; (ii) expanding coverage of central government accounts by including extrabudgetary and local government operations; (iii) developing GFS metadata on concepts, scope, classifications, basis of recording, data sources, and statistical techniques for posting on the GDDS website; (iv) adopting the Fund's 2001 Government Finance Statistics Manual (GFSM) as a coherent methodological framework for the production and dissemination of monthly, quarterly, and annual fiscal data. This would promote the recording of all assets and liabilities on accrual basis and at market values. To this end, STA has trained two CBL staff, one in 2007 and one in 2008.

\section{Balance of payments}

11. Since 2000 annual balance of payments data have been regularly reported to STA in the BPM5 format. Nonetheless, the balance of payments data suffer from deficiencies, mainly due to: (i) unclear methodology; (ii) outdated surveys; (iii) lack of component detail; (iv) lack of comprehensive coverage of trade data; and (v) methodological flaws in the compilation of the financial account.

12. To improve the balance of payments statistics, the 2005 STA mission made the following recommendations: (i) include provisions in the Bank Law for mandatory reporting by all resident sectors of data needed for compilation of balance of payments (with the CBL as the legally authorized compiling agency and with penalties for noncompliance, misreporting, breach of confidentiality, etc); (ii) institutionalize regular coordination 
meetings of the CBL with NIDA, the ministry of finance (customs department), the ministry of planning and other ministries/agencies, and private sector enterprises that can provide external sector source data; (iii) urge high-level staff to seek training opportunities, including IMF courses on balance of payments statistics; and (iv) develop computer programs for compiling balance of payments statistics in BPM5 format and move to electronic reporting by reporting agencies. In addition, a number of actions were proposed, aiming at (i) bringing balance of payments compilation in line with the BPM5 on residency/nonresidency criteria, recording basis (accrual principle), valuation (market price), coverage, etc; (ii) improving the source data, including by conducting surveys on foreign direct investment, services, and transfers and a survey to establish a business registry; (iii) improving the coverage of foreign direct investment and portfolio investment data by surveying relevant foreign-based oil companies and companies outside the hydrocarbon sector; (iv) improving the coverage of the income account by including all transactions of the LFB and the oil companies employing nonresidents; and (v) compiling foreign trade statistics using internationally accepted concepts and definitions.

13. A METAC mission visited the CBL, during February 11-22, 2007 to assess progress in developing the institutional infrastructure for compiling balance of payments statistics; provide technical advice on improving balance of payments data collection systems; and identify specific areas for further technical assistance in improving the data compilation system. Following meetings with various banks and governmental agencies, the mission drafted agency-specific forms for the CBL's use in collecting relevant source data. The mission was informed that an interagency committee was established in 2006 by the ministry of planning to address the issue of coverage deficiencies in external trade statistics. The METAC mission that visited Tripoli during January 27 and February 7, 2008 found that the implementation of most recommendations was pending. The majority of the surveys of the nonbank sector and the recommendation on the interagency committee on foreign trade statistics are yet to be implemented. The need for the National Oil Company (NOC) to provide more detailed information on its import/export transactions, and for customs to address recording issues on the customs declarations forms are among the critical recommendations that require decisive action. While recognizing the importance of introducing provisions in the Bank Law for mandatory reporting by all resident sectors of data needed for compilation of balance of payments, and for increasing staff resources for balance of payments compilation, the mission noted that the current staff was equipped with the basic skills for implementing the work program agreed with METAC. 


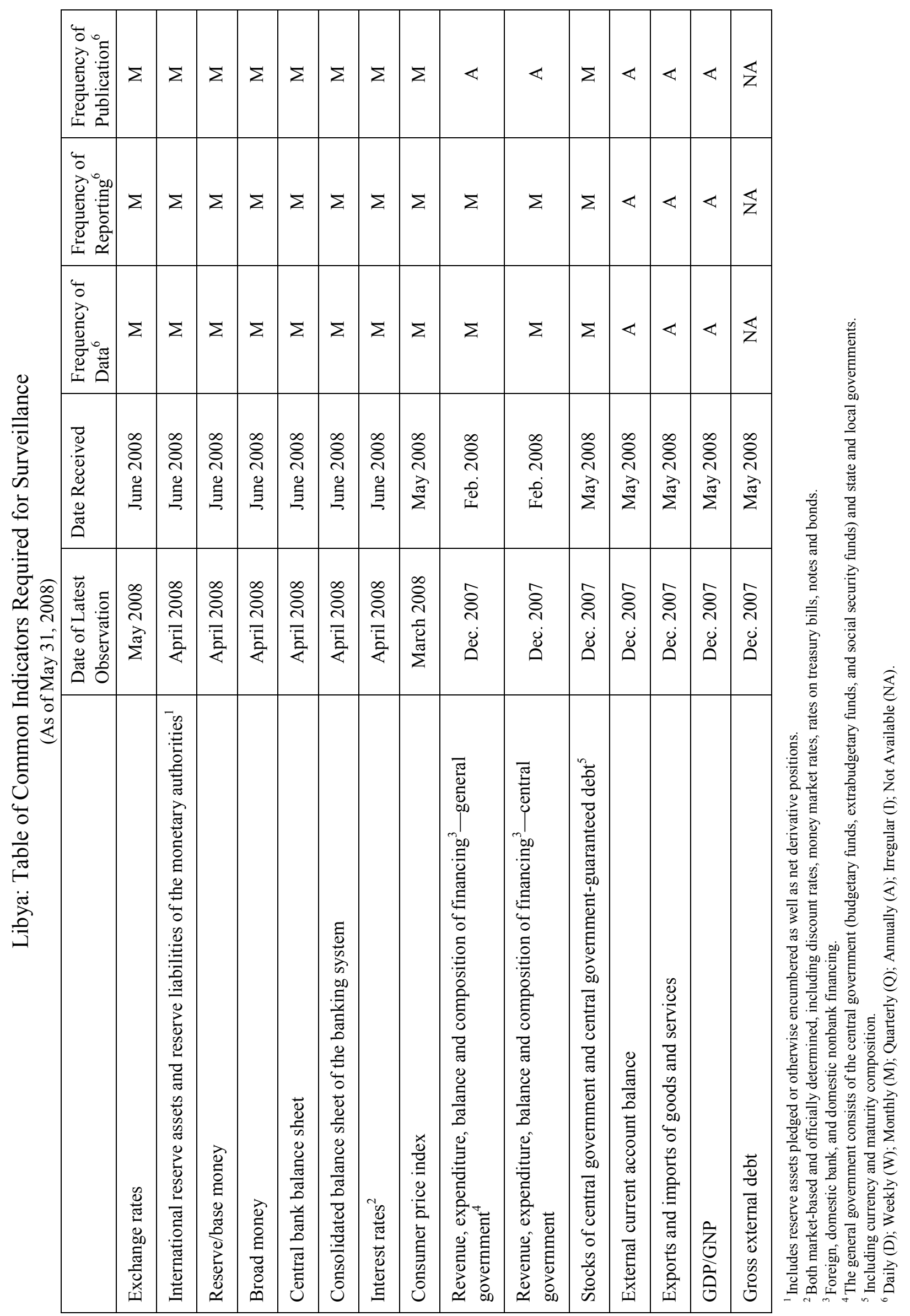




\section{IMF Concludes 2008 Article IV Consultation with The Socialist People's Libyan Arab Jamahiriya}

On July 18, 2008, the Executive Board of the International Monetary Fund (IMF) concluded the Article IV consultation with the Socialist People's Libyan Arab Jamahiriya. ${ }^{8}$

\section{Background}

Since the lifting in 2003-04 of the UN sanctions, which lasted more than 10 years, Libya has launched a series of structural reforms and accelerated its transition to "people's capitalism." The normalization of diplomatic relations with the U.S. and the EU in the second half of 2007 has contributed to increased foreign investors' interest, particularly in the hydrocarbon, banking, and infrastructure sectors. However, while progress has been made in recent years to liberalize the economy, it remains largely state controlled and heavily dependent on hydrocarbon resources. Crude oil and gas accounted for about 70 percent of GDP, 90 percent of total government revenues, and 98 percent of total exports in 2007.

A Wealth Distribution Program (WDP) was launched in March 2008 to distribute part of the oil wealth to the population and reduce the size of the government. Disbursements will be in the form of both cash and shares in projects. The initially announced amount was

\footnotetext{
${ }^{8}$ Under Article IV of the IMF's Articles of Agreement, the IMF holds bilateral discussions with members, usually every year. A staff team visits the country, collects economic and financial information, and discusses with officials the country's economic developments and policies. On return to headquarters, the staff prepares a report, which forms the basis for discussion by the Executive Board. At the conclusion of the discussion, the Managing Director, as Chairman of the Board, summarizes the views of Executive Directors, and this summary is transmitted to the country's authorities. This PIN summarizes the views of the Executive Board as expressed during the July, 18, 2008 Executive Board discussion based on the staff report.
}

Washington, D.C. 20431 • Telephone 202-623-7100 • Fax 202-623-6772 • www.imf.org 
LD 25-30 billion (\$20-25 billion), but subsequently only LD 4.6 billion ( $\$ 3.8$ billion) were approved for this year. The authorities are still considering the size, form, and modalities of the annual distributions in the years ahead.

Macroeconomic performance strengthened further in 2007, notwithstanding an acceleration in inflation. Real GDP grew by 6.8 percent, supported by an expansion in the hydrocarbon sector (3.9 percent) and a rapid increase in nonhydrocarbon activities (10.3 percent). Growth was particularly strong in construction, transportation, and trade. At the same time, average inflation increased substantially to 6.2 percent, largely driven by higher food prices and a marked increase in public expenditure. Inflation accelerated further in the first quarter of 2008, averaging about 12 percent (year-on-year).

Despite higher oil revenues, Libya's fiscal surplus in 2007 narrowed to 26 percent of GDP, compared to 35 percent in 2006 . This reflected a rapid increase in virtually all expenditure items (45 percent), albeit at a slightly slower rate than what was envisaged in the budget. The decision to raise public wages resulted in an increase in the wage bill of around 50 percent. Capital expenditure also grew rapidly.

On the external side, The current account surplus declined to 34 percent of GDP, compared to 46 percent in 2006, due to a marked increase in imports (33 percent). Continued high oil exports resulted in a further build up of the net foreign assets of Central Bank of Libya (CBL) to almost $\$ 80$ billion. The real effective exchange rate of the dinar appreciated by 1 percent in 2007, and about 5 percent in the first quarter of 2008 due to the combined effects of the rising inflation and the strengthening of the euro against the SDR (to which the dinar is pegged).

Broad money growth accelerated to 41 percent in 2007, reflecting the substantial increase in net foreign assets and the rapid increase in public expenditure, including on-lending by SCls. Credit extended to the nongovernment sector by these institutions grew by about 36 percent, while that extended by commercial banks grew by about 15 percent. Interest rates remained low and became negative in real terms with the rise in inflation. In an effort to address excess liquidity, the $\mathrm{CBL}$ recently increased its policy interest rate to 2.25 percent and the reserves requirement to 20 percent. It introduced in May 2008 its own certificates of deposit as part of its ongoing effort to enhance the monetary policy framework.

The Libyan Investment Authority (LIA) was established in March 2007. The authorities plan to invest the LIA's initial \$40-50 billion mostly abroad on a commercial basis and ensure that the LIA will be run by a qualified and independent management. Recent enhancements of its operational framework are largely in line with staff's recommendations.

Progress has been made in various structural reforms, partly in line with past Fund TA recommendations and the Medium-Term Reform Strategy (Country Report 06/137). A sound framework for the management of the oil wealth has been established through the creation of 
the LIA. Customs administration has been reformed and a large taxpayer's office established; the presentation of the budget has been consolidated and a macrofiscal unit initiated; a large number of public enterprises have been privatized; and one third of public employees are being retrenched to the private sector. Two large state-owned banks were privatized in 2007 and 2008, and two of the three remaining public commercial banks were merged in April 2008. Most regional banks have also been merged into one bank, and agreement has been reached with financial institutions from UAE and Qatar to establish two new banks.

Libya's debt relief to heavily indebted poor countries (HIPCs) continues to be based on forgiving interest payments and using a combination of swaps and rescheduling of principal. The authorities indicated that agreements based on these modalities have already been reached with some HIPCs, and that negotiations are ongoing with others.

\section{Executive Board Assessment}

Executive Directors welcomed Libya's continued solid macroeconomic performance, as reflected in the acceleration in GDP growth-in particular in the non-hydrocarbon sector-and the large fiscal and external current account surpluses, based on both the favorable external environment and the authorities' ongoing economic reforms. Directors agreed that Libya's medium-term outlook remains positive, but underscored the need to reverse the recent acceleration in inflation - caused in particular by the increase in food prices-and to further advance structural reforms in the period ahead, in support of the authorities' welcome initiative to speed up the transition from a state-dominated to a market economy.

Directors stressed that efforts to contain inflation should focus on tightening the fiscal stance by limiting the rapid increase in public expenditure, which could also pose risks for expenditure quality. They welcomed the authorities' plans to limit any further increases in public sector wages and to complete the civil service reform. While recognizing the need to upgrade the infrastructure, Directors encouraged the authorities to continue to prioritize public investment and to stand ready to scale back more of the planned projects if inflationary pressures do not recede. Public financial management also needs to be strengthened further, including by unifying the process of budget preparation and implementation under the Ministry of Finance.

Directors welcomed the authorities' decision to limit the scope of the Wealth Distribution Program (WDP) in 2008-while maintaining the focus on strengthening human capitalagainst the background of the economy's absorptive capacity constraints and increased inflation. This conservative approach will need to be maintained in the period ahead in order to avoid crowding out priority spending, to discourage rent-seeking activities, and to further reduce inflationary pressures. Directors considered that the planned reform of the public administration in the context of the WDP could present an opportunity to address inefficiencies, but care should be taken not to jeopardize the delivery of essential public 
services. They recommended that the authorities consider the reform plans carefully in consultation with the World Bank.

Directors commended the authorities for launching the Libyan Investment Authority (LIA) in a transparent fashion, and the recent enhancement of its operational framework. They emphasized the importance of limiting domestic investments by the LIA. Directors encouraged the authorities to continue to enhance the operational framework of the LIA in line with the evolving best practices for sovereign wealth funds.

Directors commended the recent efforts of the Central Bank of Libya $(\mathrm{CBL})$ to tighten monetary policy by raising both the $\mathrm{CBL}$ policy interest rate and the reserves requirement. They noted that greater reliance on indirect monetary policy instruments would be beneficial, and in this regard, they welcomed the recent introduction of $\mathrm{CBL}$ certificates of deposit.

Directors commended the authorities for the progress made in bank privatization and restructuring. They encouraged the authorities to finalize the plans to privatize the two remaining public commercial banks. It would also be important to establish an independent bank restructuring agency that would take over ownership of the specialized credit institutions and oversee their restructuring and privatization.

Directors agreed that the dinar's peg to the SDR has served Libya well as it provides a strong monetary anchor while allowing some flexibility in the dinar's exchange rate vis-à-vis individual major currencies. An eventual move to greater exchange rate flexibility would be beneficial, but would need to be gradual and preceded by a switch to market-based monetary management and development of expertise in foreign exchange markets. Directors took note of the staff assessment that the dinar is moderately undervalued at present, but that this undervaluation is likely to be transitory given the expected evolution of the fiscal and current account positions based on current policies.

Directors welcomed the authorities' commitment to continue to improve economic and financial statistics in order to facilitate better monitoring and analysis of developments to guide policy formulation. They urged the authorities to establish an AML/CFT framework in line with international standards.

Directors encouraged the authorities to continue to provide full debt relief to heavily indebted poor countries in line with the HIPC Initiative. 
Public Information Notices (PINs) form part of the IMF's efforts to promote transparency of the IMF's views and analysis of economic developments and policies. With the consent of the country (or countries) concerned, PINs are issued after Executive Board discussions of Article IV consultations with member countries, of its surveillance of developments at the regional level, of post-program monitoring, and of ex post assessments of member countries with longer-term program engagements. PINs are also issued after Executive Board discussions of general policy matters, unless otherwise decided by the Executive Board in a particular case. 
Libya: Basic Economic and Financial Indicators, 2004-07

(Quota = SDR 1,123.7 million)

Population (million): 6.04 million (2007)

Per capita GDP: US\$11,484 (2007)

\begin{tabular}{|c|c|c|c|c|}
\hline & 2004 & 2005 & 2006 & $\begin{array}{c}2007 \\
\text { Prel. }\end{array}$ \\
\hline & \multicolumn{4}{|c|}{ (Annual percent changes) } \\
\hline \multicolumn{5}{|l|}{ National income and prices } \\
\hline Real GDP & 6.0 & 9.9 & 5.9 & 6.8 \\
\hline Nonhydrocarbons & 6.8 & 13.6 & 7.9 & 10.3 \\
\hline Hydrocarbon & 5.5 & 7.2 & 4.3 & 3.9 \\
\hline CPI inflation & 1.0 & 2.9 & 1.4 & 6.2 \\
\hline & \multicolumn{4}{|c|}{ (In percent of GDP) } \\
\hline \multicolumn{5}{|l|}{ Central government finance } \\
\hline Revenue & 53.6 & 62.9 & 65.1 & 61.4 \\
\hline of which : Hydrocarbons & 46.4 & 58.5 & 60.2 & 55.2 \\
\hline Nonhydrocarbon & 7.2 & 4.5 & 4.9 & 6.2 \\
\hline Expenditure and net lending & 39.7 & 32.1 & 29.5 & 35.2 \\
\hline Current & 23.5 & 13.9 & 13.4 & 14.2 \\
\hline Capital & 16.2 & 18.2 & 16.2 & 21.0 \\
\hline Overall fiscal balance & 13.9 & 30.9 & 35.5 & 26.2 \\
\hline Nonhydrocarbon balance (deficit -) & -32.5 & -27.6 & -24.7 & -29.0 \\
\hline & \multicolumn{4}{|c|}{ (Annual percent changes, unless otherwise specified) } \\
\hline \multicolumn{5}{|l|}{ Monetary indicators } \\
\hline Broad money & 13.3 & 30.6 & 15.3 & 40.8 \\
\hline Deposit rates ( 1 year deposits, in percent) & 4.5 & 4.5 & 4.5 & 4.5 \\
\hline Claims on the economy & -1.1 & 8.4 & 11.7 & 14.5 \\
\hline & \multicolumn{4}{|c|}{ (In billions of dollars, unless otherwise specified) } \\
\hline \multicolumn{5}{|l|}{ External sector } \\
\hline Exports of goods & 20.4 & 31.4 & 39.2 & 44.5 \\
\hline of which: Hydrocarbons & 19.5 & 30.5 & 38.2 & 43.4 \\
\hline Imports of goods & 8.8 & 11.2 & 13.1 & 17.4 \\
\hline Current accounts balance & 7.4 & 17.4 & 25.2 & 23.8 \\
\hline In percent of GDP & 22.3 & 38.4 & 45.8 & 34.0 \\
\hline Net foreign assets of $\mathrm{CBL}$ & 25.9 & 39.3 & 58.7 & 78.8 \\
\hline of which: Net international reserves & 16.2 & 23.0 & 27.9 & 35.7 \\
\hline (In months of next year's imports) & 14.4 & 17.4 & 16.2 & 15.7 \\
\hline Real effective exchange rate (percent change) & -8.50 & 9.11 & -3.14 & 0.40 \\
\hline
\end{tabular}

Sources: Libyan authorities; and Fund staff estimates. 


\section{Statement by Shakour Shaalan, Executive Director for Socialist People's Libyan \\ Arab Jamahiriya \\ July 18, 2008}

1. On behalf of the Libyan authorities, I thank staff for the productive discussions on the 2008 Article IV Consultation mission, and the highly appreciated technical assistance support that the Fund is providing. The authorities also value the continued constructive engagement of management and the Board on policy and reform priorities.

\section{Recent Developments}

2. For the fourth consecutive year, economic expansion in Libya continued at a brisk pace in 2007, underpinned by buoyant oil prices and strengthened foreign investor's interest. At 6.8 percent, GDP growth was the highest among the Maghreb countries. The expansion was broad based and driven by a sharp acceleration in non-hydrocarbon activity at over 10 percent. The dominant sources of non-hydrocarbon growth were construction, transportation, and trade. The fiscal and external positions continued to post sizable surpluses, and the rapid accumulation of net foreign assets by the Central Bank of Libya (CBL) further reinforced Libya's strong net external creditor position. At the same time, meaningful strides in the implementation of important structural reforms were achieved, including banking sector, civil service and trade reforms. These accomplishments are testament to the authorities' determination to transform Libya from a state-dominated to a market economy.

3. Not surprisingly, and as commonly observed in many countries, price pressures have lately emerged, reflecting largely rising world food prices. The authorities, nevertheless, recognize the important role of fiscal policy in containing inflationary pressures. To this end, they are in the process of trimming down planned capital outlays in line with the economy's absorptive and implementation capacity to safeguard macroeconomic stability. At the same time, close attention is being accorded to project selectivity, prioritization and sequencing, which will also help preserve the quality of public spending and minimize bottlenecks. Moreover, access to budget financing by specialized credit institutions (SCIs) is being restricted. Additionally, they have tightened monetary conditions recently as part of their proactive response to curb inflation. These measures, along with the expected stabilization of international food prices, underlie the projected gradual decline in inflation from 2009 and beyond. Moreover, the authorities have recently established a ministerial committee to monitor inflation developments and take further policy actions as appropriate.

\section{Outlook and Policies}

4. The authorities share staff's assessment that Libya's medium-term outlook remains positive. Overall GDP growth is expected to remain very strong, owing to favorable oil market outlook and increased investments in infrastructure and hydrocarbon sectors. These investments are expected to set the stage for a higher productivity growth and output potential over the medium-to-long term. In spite of this, the authorities are cognizant of the fact that the country's favorable prospects are not without risks. Accordingly, they remain committed to sustaining robust growth, including by further promoting diversification through greater private sector and foreign-investor participation, accelerating the implementation of structural reforms, progressing with the execution of necessary investments in the hydrocarbon sector, and most importantly addressing the country's infrastructure bottlenecks. 


\section{Fiscal Developments, Policies, and Reforms}

5. Fiscal policy in 2007 continued to aim at achieving a balance between the need to increase development spending to support solid long-term growth and saving part of the revenue from nonrenewable resources to attain a sustainable source of revenue, with a view to reducing dependency on oil. The fiscal position remained strong, with the overall fiscal surplus estimated at about 26 percent of GDP, supported by buoyant hydrocarbon revenues. Moreover, improvements in custom and revenue administration have already started to pay-off, as reflected in the rapid increase in nonhydrocarbon tax revenue. On the expenditure side, the majority of the increase in public expenditure in 2007 was channeled to much-needed capital outlays. The increase in wages was necessary, given their low base. More importantly, the rise in public sector wages was accompanied by the commencement of a large civil service reduction program. Furthermore, substantial progress has been made on important structural fiscal reforms, including the establishment of a large taxpayer's office, the initiation of a macro-fiscal unit, and the consolidation of the budget's presentation. In addition, a large number of public enterprises have been privatized, and the authorities are considering public-private-partnerships for utilities and other projects to enhance efficiency of public services delivery.

6. In March 2007, the authorities established the Libyan Investment Authority (LIA) to manage the state's financial assets, including the Oil Reserve Fund, with a view to ensuring a sound framework for the management of oil wealth. They plan to invest the LIA's initial \$40-50 billion, mostly abroad, on a commercial basis through qualified and independent international managers. Transfers from the LIA to the budget will be limited to its profits. The LIA intends to meet high transparency and operational standards. The LIA decree issued in March 2008 largely incorporates staff's recommendations, and its operational framework was further enhanced.

7. Fiscal policy in 2008 continues to aim at accommodating Libya's ongoing investment program, although the share of capital expenditure in GDP is expected to decline. The 2008 budget also accommodates the recently initiated Wealth Distribution Program (WDP), as the authorities underscore the importance of sharing the oil wealth with the population. In addition to its equity objectives, the WDP aims at reducing the size of the government and encouraging private sector activity. Only a relatively small amount was approved for distribution in 2008 under the WDP. In this respect, it is well to note that the resulting increase in transfers is being accompanied by a stabilization in the wage bill. The authorities are still considering the size, form and modalities of the annual distributions for the period ahead. They intend to consult with the World Bank on their public administration reform plans as they emerge.

8. Looking beyond 2008, the authorities are intent on keeping fiscal policy in line with maintaining a large fiscal surplus and alleviating inflationary pressures. In addition, they will preserve with their efforts aimed at boosting non-hydrocarbon revenues. They appreciate the fiscal sustainability analysis, and share the staff's assessment that, based on current policies, Libya's fiscal position is sustainable. It is well to note that public finances remain resilient to slides in oil prices as low as $\$ 90$ per barrel — an unlikely scenario given what is probably a structural shift in world oil prices. Moreover, the analysis confirms that the current fiscal stance is consistent with preserving intergenerational equity. 


\section{Monetary, Financial Sector, and Exchange rate Issues}

9. Libya continues to implement reforms aimed at modernizing its monetary policy framework and developing its financial sector. Broad money growth accelerated in 2007, owing to the substantial increase in net foreign assets and the rapid increase in public spending, including onlending by SCIs. The authorities consider the primary sources of rising CPI inflation to be basically not monetary, with the rise in food prices being the largest contributor to inflation. Notwithstanding the limited scope for monetary policy given the exchange rate peg, the CBL intensified its efforts to tighten monetary conditions to help reduce excess liquidity. In this respect, both interest rates and reserve requirements were raised in May 2008. Moreover, with Fund TA, the CBL has recently introduced its own certificates of deposit, which should increase the scope for enhanced liquidity management through greater reliance on market-based instruments. At the same time, it embarked on an extensive technical cooperation program with the Fund to modernize its structure and enhance the payment system, with a view to improving its capacity to conduct a more proactive monetary policy, going forward.

10. Commercial banks are well-capitalized, with the overall capital adequacy ratio at about 15 percent at end-2007. Non-performing loans, while still high, continued to decline. The authorities recognize the importance of a sound financial system to support non-hydrocarbon growth. In this respect, substantial progress has been made in banking sector reforms, including bank privatization and restructuring, as well as further strengthening bank supervision. On bank privatization, which started in 2007, two of the five public commercial banks have already been privatized to reputable foreign banks, with immediate management control and option to purchase additional shares of up to 51 percent within 3-5 years. Two of the remaining three banks merged in April 2008, and most regional banks have been also merged into one bank. Going forward, the authorities plan to privatize the remaining two public commercial banks through the newly-established stock market. Moreover, an agreement has been reached with financial institutions from the U.A.E and Qatar to establish two new banks.

11. On banking supervision, the CBL, based on Fund TA recommendations, is improving its off-site surveillance techniques, loan classification, and capital adequacy calculations. Furthermore, a technical cooperation agreement with the Fund in banking supervision has been reached. The authorities recognize the risks posed by SCIs to financial intermediation and development. In this connection, they intend to strengthen CBL's supervision of SCIs, while consideration is also being given to contracting international consultants to design an action plan to reform the SCIs. These reforms, together with the opening up of the market to foreign banks, have laid the basis for a competitive banking sector.

12. The dinar's peg to the SDR has served Libya well by providing a credible monetary anchor, while allowing some flexibility in the dinar's exchange rate vis-à-vis individual major currencies. It is well to note that the high degree of volatility in oil prices and the large degree of dependence on oil exports compound the serious methodological weaknesses of the CGER methodology for exchange rate assessment, and highlight the inherent difficulties in the application of the 2007 Surveillance Decision to oil producing countries. Therefore, the authorities agree that the results of the exchange rate assessment should be treated as indicative and interpreted with caution. 


\section{Other Reforms and Issues}

13. Continued progress has been made in trade reforms, including the ongoing harmonization of financial regulations, statistical frameworks, and payment settlement systems with other Maghreb countries, as well as the simplification of certification requirements for trade with these countries. Moreover, custom duties on almost all imports have been abolished. Technical assistance support from the World Bank on WTO accession is planned for FY 2009.

14. The Libyan authorities remain committed to further improving the quality, dissemination, and timeliness of economic and financial data to better guide policy formulation. They have recently benefited from the expertise of a resident national accounts statistics advisor to assist in implementing the Fund's Statistics Department recommendations, and improve national accounts. Going forward, they intend to enhance coordination between the various levels of government while addressing capacity and staffing limitations over the medium term.

15. Following its withdrawal from the HIPC imitative, Libya has developed its own debt relief plan. It continues to provide generous debt relief to HIPCs who negotiate in good faith, based on interest payments forgiveness and a combination of swaps and rescheduling of principal. Agreement based on these modalities have been reached with some HIPCs, while others are still under negotiations. 